\title{
Илья Федорович Копиевский (Жизнь и судьба одного просветителя петровского времени) $)^{1}$
}

\section{Il'ia Fedorovich Kopievskii (The Life and Fate of an Enlightener in the Age of Peter the Great)}

\author{
Юрий Зарецкий \\ Национальный университет - Высшая школа экономики \\ Yury Zaretsky \\ National Research University - Higher School of Economics \\ yzaretsky@hse.ru
}

\begin{abstract}
:
In 1699, on the initiative of Peter the Great, the printing of Russian secular books began in Amsterdam. Most of these publications were textbooks on history, arithmetic, astronomy, navigation, and foreign languages. The compiler, translator, and publisher of these books was a native of the lands of the Grand Duchy of Lithuania, Ilya Fedorovich Kopievsky (or Kopievich). For many decades, historians have turned to the biography of this man, but it is still full of gaps and factual errors. This article, which summarizing the various information about Kopievsky available today (from archival documents to the latest works of historians), contains a detailed reconstruction of his life path. It also includes materials to return to the question of the contribution of this enlightener to the cultural reforms of Peter the Great.
\end{abstract}

Keywords:

Il'ia Kopievskii, biography, textbooks, Peter the Great

Весьма было бы похвально, если бы кто-нибудь из ревности к руской словесности, тщательнее разыскал нам о произхождении и сочинениях сего ученаго мужа времен Петра Великаго. Неужели все сие так маловажно, что ни один руской биограф, ни один руской путешественник ... не читали, ни от кого не слыхали, и никого не разспрашивали о своем соотечественнике? Сего бы требовало и само любочестие Рускаго.

- А. А. Писарев. Илия Копиевич

\footnotetext{
${ }^{1}$ Работа подготовлена по результатам проекта “Перевод и трансфер: западная литература в зеркале русской культуры (XVII-XXI вв.)” при поддержке фонда “Гуманитарные исследования” ФГН НИУ "Высшая школа экономики" в 2021 году.

${ }^{2}$ А. А. Писарев, "Илия Копиевич," Соревнователь просвещения и благотворения, ч. 28 (1824), 52. (А. A. Pisarev, "Iliia Kopievich," Sorevnovatel' prosveshcheniia i blagotvoreniia, ch. 28 (1824), 52).
} 


\section{Fama}

\section{В Европе}

В феврале 1710 г. в разделе “Новости литературы” авторитетного французского периодического издания Журналь де треву под заголовком “Из Московии" была опубликована заметка об успехах культурных преобразований Петра:

Заботы царя Петра Алексеевича о воспитании у своих подданных воинского духа и литературного вкуса увенчиваются успехами. Победа, одержанная под Полтавой, показывает, насколько московитское войско изменилось после Нарвской битвы. Большое количество полезных книг, созданных на славянском языке или переведенных на этот природный язык Московии, доказывает, что московиты не далеки от того, чтобы с помощью наук снискать себе такую же славу, какую они уже заслужили на ратном поле. Все эти книги были напечатаны шрифтами, привезенными из Голландии. ${ }^{3}$

Дальше в ней приводились названия семи книг, напечатанных в Москве гражданским шрифтом в 1708-1709 гг., и отдельно следовало добавление: “Илья Копиевич переводит Квинта Курция на тот же язык. Скоро появится и много других книг."

В июньском номере Журналь за тот же год литературные вести из Московии начинались уже сразу с имени Копиевского: “Очень высоко оценен элегантный перевод Горация на славянский язык, который царь приказал сделать господину Илье Копиевичу, одному из своих секретарей, автору славянского перевода Квинта Курция и нескольких других книг." Наконец, в сентябрьском номере следующего 1711 года в заметке "Новая литература из Московии" сведения о Копиевском и его трудах давались в подробностях. Начиналась заметка с повторения традиционного суждения европейцев о бедственном положении наук в России, вслед за которым шло описание успехов военных реформ Петра и приводились свидетельства его первых успешных преобразований в области словесности:

Вот литературные новости из страны, которая лишь недавно начала поставлять материал для истории науки. Эта обширная империя, погребенная в глубоком невежестве, обязана тем блеском, который она начинает извлекать из изящных искусств, одному единственному человеку. За пятнадцать лет царь Петр Алексеевич создал и обучил военному делу огромную армию, множество

\footnotetext{
${ }^{3}$ Mémoires pour l'histoire des sciences $\mathcal{E}$ des beaux-arts (Journal de Trévoux) (Fevrier 1710), 352. Цит. по: Н. А. Копанев, “Петр I - переводчик," в Итоги и проблемы изучения русской литературы XVIII в. (Ленинград: Наука, 1989), 18о. (N. A. Kopanev, "Petr I - perevodchik," in Itogi i problemy izucheniia russkoŭ literatury XVIII v. (Leningrad: Nauka, 1989), 180).

${ }^{4}$ Mémoires pour l'histoire des sciences (Fevrier 1710), 353.

${ }^{5}$ Mémoires pour l'histoire des sciences (Juin 1710), 1098. Цит. по: Копанев “Петр I - переводчик,” 181. (Kopanev, “Petr I - perevodchik,” 181).
} 
офицеров, нескольких генералов - и это в стране, где редко встретишь хорошего солдата. Он, если можно так выразиться, построил, вооружил, создал, флот из семидесяти судов, причем снаряжают его и командуют им московиты, в чьем языке даже не было слова, означающего “флот.” Намерение улучшить (perfectionner) своих подданных не ограничилось военной сферой. Он также сумел своими дарами привлечь выдающихся ученых мужей своих государств, он основал учебные заведения, он - своим примером, а также с помощью вознаграждений - побудил своих подданных любить науки; он повелел перевести и напечатать целый ряд книг, написанных очень рассудительно. ${ }^{6}$

Сразу после этого называлось имя Копиевского как человека, более других русских способствовавшего устремлениям Петра по просвещению народа: “Илья Копиевич - тот из его подданных, кто лучше всех помог в осуществлении его замыслов в области литературы" (Elie Kopieuvicz est celui de tous ses sujets qui a le mieux servi ses desseins pour la literature). ${ }^{7}$ Затем воздавалась хвала его таланту и усердию: “произведения, которые он уже опубликовал и подготовил к публикации, являются неоспоримыми доказательствами щедрости его счастливого гения и его неустанной преданности работе." ${ }^{8}$ И в самом конце приводился список из 24 названий книг Копиевского во французском переводе изданных, подготовленных к печати и тех, работу над которыми он планировал. 9 Очень скоро фрагменты этих сообщений появились в лондонском периодическом издании Memoirs of Literature, публиковавшемся иммигрировавшим в Англию гугенотом Мишелем де Ла Рош. Заметка от 27 марта 1710 года была почти дословным переводом заметки в февральском номере Журналь за этот же год. Она также заканчивалась известием о том, что Илья Копиевич переводит Квинта Курция, и обещанием, что в скором будущем благодаря его стараниям выйдет еще несколько русских книг. ${ }^{10}$ Дополнением к ней стало сообщение, появившееся 17

\footnotetext{
${ }^{6}$ Mémoires pour l'histoire des sciences (Septembre 1711), 1657. Перевод Ю. В. Ткаченко.

${ }^{7}$ Mémoires pour l'histoire des sciences (Septembre 1711), 1657-1658. Перевод Ю. В. Ткаченко.

${ }^{8}$ Mémoires pour l'histoire des sciences (Septembre 1711), 1658. Цит. по: Копанев, “Петр I - переводчик," 181-182. (Kopanev, "Petr I - perevodchik," 181-182). В оригинале: "Les ouvrages qu'il a deja imprimez, \& ceux qu'il va imrimer, sont des preuves indubitables de la facilité de son heureux genie \& de son application infatigible au travail."

9 Этот список почти целиком повторял опубликованный Копиевским на латинском в его “Руковедении в грамматыку”: И. Ф. Копиевский, Руковедение в грамматыку, во слаяноросийскую или Московскую. Ко употреблению учащыхся языка Московскаго (Штольценберг: Печатал Ф. Гольциус, 1706). (I. F. Kopievskii, Rukovedenie v grammatyku, vo slavianorosiiskuiu ili Moskovskuiu. Ko upotrebleniiū uchashchykhsia iazyka Moskovskago (Shtol'tsenberg: Pechatal F. Gol'tsius, 1706)). Исключения составили переводы Истории Александра Квинта Курция и Горация (какого именно сочинения не указано), которые во французском издании значатся как опубликованные (р. 1658). Ю. К. Бегунов считал, что этот рукописный перевод Горация под названием $O$ добродетели хранится сегодня в БАН (Собр. Петровской галереи, № 31). - Ю. К. Бегунов, “Копиевский (Копиевич)," в Словарь русских писателей XVIII века, вып. 2 (Санкт-Петербург: Наука, 1999), 123. (Iu. K. Begunov, "Kopievskii (Kopievich)," Slovar' russkikh pisatelei XVIII veka (St. Petersburg: Nauka, 1999), vyр. 2: 123). Об истории издания Копиевским "Руковедения в грамматыку” см. в статье дальше.

${ }^{10}$ Memoirs of Literature (London: R. Knaplock, 1722), vol. 1: 21-22.
} 
июля и целиком посвященное Копиевскому: “Илья Копиевич, один из секретарей его Царского Величества, опубликовал по указу этого государя прекрасный перевод Горация на славянский язык. Этот джентльмен также перевел Квинта Курция и несколько других книг на язык Московии."

Благодаря этим публикациям имя Копиевского и его просветительская деятельность в России стали достоянием европейского ученого сообщества и через некоторое время сведения о нем вошли в авторитетные словари и энциклопедии. ${ }^{12}$ Сначала - во второе издание Большого исторического словаря Морери (1740), где повторялись сообщения Журналь де треву за сентябрь 1711 г. (в том числе и ошибочное утверждение о том, что Копиевский был урожденным московитом, и что Петр в 1698 г. взял его с собой в Великое посольство). ${ }^{13}$ А затем - в знаменитый биографический словарь Мишо, также почти дословно пересказывавший сообщения Журналь. Копиевский был назван здесь русским филологом XVII века, который своими способностями привлек внимание царя Петра и благодаря благодеяниям своего господина “достиг больших успехов в словесности и истории (fit de grands progrès dans la litterature et dans la histoire)."14

\section{В России}

Возможно, именно на эту статью словаря Мишо отозвался Пушкин, поместив в Apane Петра Великого Копиевского в число образованнейших людей из окружения царя: "Ибрагим видал Петра в сенате, оспориваемого Бутурлиным и Долгоруким, разбирающего важные запросы законодательства, в адмиралтейской коллегии утверждающего морское величие России, видел его с Феофаном, Гавриилом Бужинским и Копиевичем." ${ }^{15}$ Хотя во время работы над романом он мог уже пользоваться и другими, русскими материалами.

В России имя Копиевского впервые кратко упоминалось в словаре Новикова: "Копиевич, Илия, сочинил стихами панагирик, или похвальное слово на победы Петра Великаго; также сочинил Латинскую с Российским грамматику, и перевел

\footnotetext{
${ }^{11}$ Memoirs of Literature, 262.

${ }^{12}$ Краткая заметка о Копиевском была опубликована также в 1702 г. в гамбургских "Исторических записках" - Historische Remarques über neuesten Sachen in Europa des ... Jahres, vol. 4 (Hamburg, 1702), 167-168. Однако она осталась в Европе незамеченной.

${ }^{13}$ L. Moréri, Le grand dictionnaire historique, ou Le melange curiaux de l'histoire sacrée et profane (Amsterdam: Brunel, 1740), vol. $5: 44-45$.

14 "Kopieuvicz (Elie)," in Biographie universelle, ancienne et moderne, ou Histoire, par ordre alphabétique, de la vie publique et privée de tous les hommes (Paris: Chez L.G. Michaud, imprimerie-libraire, 1818), vol. XXII : 540-541.

${ }^{15}$ А. С. Пушкин, Собрание сочинений в десяти томах, т. 5 (Москва: ГИХЛ, 1960), 19. (А. S. Pushkin, Sobranie sochinenii v desiati tomakh (Moscow: GIKhL, 1960), 5: 19). Имя Копиевского появляется у Пушкина и в статье 1834 г. "О ничтожестве литературы русской” в связи с реформами Петра: “Петр не успел довершить многое, начатое им. Он умер в поре мужества, во всей силе творческой своей деятельности. Он бросил на словесность взор рассеянный, но проницательный. Он возвысил Феофана, ободрил Копиевича." См. А. С. Пушкин, Собрание сочинений в десяти томах, т. 6 (Москва: ГИХЛ, 1962), 409. (А. S. Pushkin, Sobranie sochinenii v desiati tomakh (Moscow: GIKhL, 1962), 6: 409).
} 
книгу Де графа, или морское плавание. Все сии книги напечатаны 1700 и 1701 годов в Амстердаме." Через пол столетия более подробные сведения о нем привел Н. И. Греч - сначала в Сыне отечества, а затем в двух обзорах русской литературы. ${ }^{17}$ Он стал первым, кто сообщил русским читателям о Копиевском как о переводчике и издателе, хотя и особенно не выделял его роль в петровских преобразованиях. Сразу после Греча о Копиевском как писателе и переводчике напомнил А. А. Писарев. Его статья повторяла некоторые фактические ошибки, допущенные в публикациях Греча, однако включала и новое для русского читателя: перевод заметки из сентябрьского номера Журналь де треву за 1711 г. с перечнем названий книг Копиевского. ${ }^{18}$ Не делая вывода о выдающемся вкладе Копиевского в культурные преобразования петровского времени, А. А. Писарев тем не менее указал на необходимость более обстоятельного изучения биографии этого человека и его литературного наследия. Этими несколькими заметками и статьями исчерпываются публикации на русском языке об этом человеке до того, как Пушкин в Apane Петра Великого включил Копиевского в круг приближенных царя.

Складывается впечатление, что подчеркивание весомости вклада Копиевского в русскую культуру петровского времени в иностранных энциклопедиях и словарях XVIII-XIX вв. целиком обязано заметкам в Журналь де треву. В этой связи вполне логично предположить, что тщеславный Копиевский сам эти заметки и писал. ${ }^{19}$ Однако на поверку это предположение выглядит не слишком убедительно. В сентябрьском номере Журналь за 1711 г., например, говорится, что “царь, видя в этом молодом московите ум и расположенность к наукам, послал его в 1698 г. в Голландию.” ${ }^{20}$ Сам Копиевский вряд ли мог такое написать - не только потому, что это не соответствовало действительности в принципе, но и потому, что в ученом мире Европы начала XVIII в. он был небезызвестной фигурой и не

\footnotetext{
${ }^{16}$ Н. И. Новиков, Опыт историческаго словаря о российских писателях (Санктпетербург: Тип. Акад. наук, 1772), 108-109. (N. I. Novikov, Opyt istoricheskago slovaria o rossiiskikh pisateliakh (St. Petersburg: Tip. Akad. nauk, 1772), 108-109).

${ }^{17}$ Н. И. Греч, “Илья Копиевич," Сын Отечества: исторический и политический журнал, ч. 72 (1821): 305-308. (N. I. Grech, "Il'ia Kopievich," Syn Otechestva: istoricheskii i politicheskii zhurnal, ch. 72 (1821): 305-308); Н. И. Греч, Опыт краткой истории руской литературы (Санкт-Петербург: В типографии Н. Греча, 1822), 91-92, 116-117. (N. I. Grech, Opyt kratkoi istorii ruskoi literatury (St. Petersburg: V tipografii N. Grecha, 1822), 91-92, 116-117); Н. И. Греч, Учебная книга российской словесности или Избранныя места из руских сочинений и переводов в стихах и прозе: С присовокуплением кратких правил риторики и пиитики, и истории российской словесности, ч. 4, отд-ние 2: Поэзия (СанктПетербург: В типографии издателя, 1822), 363-364; 388-389. (N. I. Grech, Uchebnaia kniga rossiǔskoi slovesnosti ili Izbrannyia mesta iz ruskikh sochinenii i perevodov v stikhakh i proze: $S$ prisovokupleniem kratkikh pravil ritoriki i piitiki, i istorii rossiuskoŭ slovesnosti, ch. 4, otd-nie 2: Poėziia (St. Petersburg: V tipografii izdateliā, 1822), 363-364; 388-389). Откуда именно Греч взял эти сведения мне установить не удалось, ясно лишь, что он повторял ошибки некоторых своих предшественников, в частности, утверждал, что Копиевский скончался в том же году, что и Тессинг (1701).

${ }^{18}$ А. А. Писарев, “Илия Копиевич," 44-52. (А. A. Pisarev, "Iliia Kopievich," 44-52).

${ }^{19}$ Такого мнения придерживался Н. А. Копанев. См. Копанев, “Петр I - переводчик," 182. (Kopanev, "Petr I - perevodchik," 182).

${ }^{20}$ Mémoires pour l'histoire des sciences (Septembre 1711), 1657. Цит. по: Копанев “Петр I - переводчик," 181. (Kopanev, "Petr I - perevodchik," 181). Ту же ошибку повторил известный российский библиограф XIX в.: В. С. Сопиков, Опыт российской библиографии, ч. 1. (Санкт-Петербург: В типографии Императорскаго театра, 1813), 300. (V. S. Sopikov, Opyt rossiiskoi bibliografii (St. Petersburg: V tipografii Imperatorskago teatra, 1813), ch. 1: 300).
} 
делал тайны из фактов своей биографии. Трудно предположить также, что он во всеуслышание бесстыдно объявлял о не существовавших публикациях своих переводов Горация и Квинта Курция - такой обман также мог быть сразу обнаружен сведущими людьми. Имеется гораздо больше оснований считать, что во французский журнал эти сообщения писал не он - или, если все же он, то только, так сказать, отчасти. Скажем, Копиевский вполне мог переправлять во Францию заметки о литературной жизни в России на латыни (о том, что Копиевский владел французским нет никаких упоминаний), которые затем кемто переводились, редактировались и печатались в Журналь. Однако все могло быть и иначе. Например, что писавший эти сообщения француз был знаком по крайней мере с одним из печатных списков книг Копиевского и имел связи с Россией. ${ }^{21}$ Или что материалом для этих публикаций стали сведения, ранее опубликованные в Германии и включавшие список латинских названий книг Копиевского $?^{22}$ Но почему во французском журнале Копиевский представляется ключевой фигурой в петровских преобразованиях культуры начала XVIII в.? Ответ на этот вопрос остается открытым. Как, впрочем, и многие другие, связанные с биографией этого человека, его сочинениями и его деятельностью по просвещению “славянороссийского народа” в целом.

\section{От рождения до сорока пяти лет}

О первых сорока пяти годах жизни Ильи Копиевского известно немного. ${ }^{23}$ Скорее всего, какие-то сведения о них можно найти в амстердамских архивах, однако до сих пор их поисками никто не занимался. По косвенным данным можно заключить, что родился он около 1651 года в землях Великого княжества

\footnotetext{
${ }^{21}$ B Bibliothèque Nationale de France (Notice ${ }^{\circ}$ : FRBNF30691930) хранится экземпляр “Латинской грамматики" Копиевского, содержащей список его книг (И. Ф. Копиевский, Latina grammatica in usum scholarum celeberrimae gentis sclavonico-rosseanae adornata (Амстердам: Типография Копиевского], 17oo). (I. F. Kopievskiĭ, Latina grammatica in usum scholarum celeberrimae gentis sclavonico-rosseanae adornata (Amsterdam: Tipografiia Kopievskogo, 17oo)). Не стал ли именно этот экземпляр источником сведений, опубликованных в Журналь?

${ }^{22}$ Historische Remarques, 167-168.

${ }^{23}$ Важнейшие сведения о биографии и изданиях Копиевского см.: П. П. Пекарский, Наука и литература в России при Петре Великом, т. 1-2 (Санкт-Петербург: Издательство товарищества “Общественная польза," 1862). (Р. P. Pekarskiŭ, Nauka i literatura v Rossii pri Petre Velikom, t. 1-2 (St. Peterburg: Izdatel'stvo tovarishchestva "Obshchestvennaia pol'za," 1862)); T. А. Быкова, Описание изданий, напечатанных кириллицей: 1689 - январь 1725 г. (Москва-Ленинград: Издательство Академии наук СССР, 1958), 278-292; 318-341. (T. A. Bykova, Opisanie izdanii, napechatannykh kirillitsei: 1689 - ianvar' 1725 g. (Moscow-Leningrad: Izdatel'stvo Akademii nauk SSSR, 1958), 278-292; 318-341); Z. Nowak, "Eliasz Kopijewicz, polski autor, tłumacz, wydawca i drukarz świeckich książek dla Rosji w epoce wczesnego oświecenia," in Libri Gedanenses: rocznik Biblioteki Gdańskiej Polskiej Akademii Nauk. t. 2-3 (1968-1969) (Gdańsk, 1970), 35-86. Подписывался Копиевский в своих письмах и книгах по-разному: "Elia Федоров Копиевский," "Elias Kopijewitz (Kopiewcki, Kopiewiz)," а в челобитной Петру еще и “Ильюшка Федоров Копиевский.” К подписи иногда добавлял, что его фамилия происходит "от копий” (Seu de Hasta Hastenii), очевидно, давая понять, что она дворянская. Иногда он еще называл себя "polonius in praesentiarum habitans Amstelodami” и указывал на принадлежность к духовному званию: человек “духовнаго чина, веры реформатския собору Амстеродамскаго” (т.е. священник Голландской реформатской церкви кальвинистской деноминации) или "Verbi Dei Minister polonus" (служитель Слова Божия, поляк).
} 
Литовского в семье мелкопоместного шляхтича протестантского вероисповедания. Однако где именно, точно не установлено.

Больше всего исторических сведений указывает на то, что это было местечко Кайданов Минского воеводства (сегодня белорусский город Дзержинск). Во второй половине XVII - начале XVIII вв. здесь жил род Копиевичей из которого происходило несколько лиц духовного звания. ${ }^{24}$ Самым известным среди них был племянник Ильи, видный протестантский деятель Великого княжества Литовского Богуслав Копиевич - начальник и суперинтендант округа. Сохранились сведения о том, что по делам общины в 1717-1718 гг. он совершил поездку в Германию, Шотландию и Англию, где удостоился аудиенции у короля Георга I. Богуслав также занимал должность проректора протестантской Слуцкой гимназии и намеревался открыть в Койданове другую, третью в Великом княжестве Литовском. ${ }^{25}$ За пол столетия до Богуслава, в 1660-1662 гг., в Слуцкой гимназии преподавательскую должность занимал еще один Копиевич, Филипп. ${ }^{26}$ Он также был видной фигурой в кальвинистской общине Великого княжества Литовского и с 1694 года исполнял в ней обязанности окружного суперинтенданта. ${ }^{27}$ В метрических книгах кальвинистской церкви Кайданова содержится еще запись о вступлении в брак Регины Копиевич (скорее всего, сестры Ильи) с Павлом Жарнавцем, также происходившем из семьи местных протестантских пасторов. ${ }^{28}$ Наконец, 15 октября 1676 г. в той же церкви был зарегистрирован брак Ильи Копиевского с местной дворянкой Еленой Жидович, четырьмя годами моложе его. ${ }^{29}$

Впрочем, некоторые историки, опираясь на косвенные данные, в качестве возможных мест рождения Ильи называют окрестности Ляховичей (сегодня в Брестской области) или округу Мстиславля (нынешняя Могилевская область). ${ }^{30}$

\footnotetext{
${ }^{24}$ Nowak, "Eliasz Kopijewicz," 46-47.

${ }^{25}$ О Богуславе Копиевиче см.: W. Kriegseisen, "Podróże i projekty pastora Boguslawa Jelitko Kopijewicza," in Ludzie - Kontakty - Kultura XVI-XVIII w. Prace ofiarowane Marii Boguckiej, eds. J. Kawecki, J. Tazbir (Warsaw: Semper, 1997), 246-52; W. Kriegseisen, Ewangelicy polscy i litewscy w epoce saskiej (1696-1763) (Warsaw: Semper, 1996), 137-143; Собрание белорусской шляхты, дата обращения, Ноября 23, 2021, http://www.nobility.by/forum/index.php?topic=3293.o. (Sobranie belorusskoŭ shliakhty, date accessed, November 23, 2021, http://www.nobility.by/forum/index.php?topic=3293.0).

${ }^{26}$ И. А. Глебов, Историческая записка о Слуцкой гимназии с 1617-16зо-1901 г2. (Вильна: Тип. А. Г. Сыркина, 1903), 183. (I. A. Glebov, Istoricheskaia zapiska o Slutskol̆ gimnazii s 1617-163o-19o1 gg. (Vil'na: Tip. A.G. Syrkina, 1903), 183).

${ }^{27}$ E. Baginska, "The Careers of Calvinist Stipendiaries from the Grand Duchy of Lithuania in the 17th Century. The Example of Gabriel Dyjakiewicz," Lithuanian Historical Studies 16 (2011), 68.

28 Собрание белорусской шляхты, дата обращения, Ноября 23, 2021, http://www.nobility.by/forum/index.php?topic=3293.0. (Sobranie belorusskoi shliakhty, data obrashcheniia, Noiabria 23, 2021, http://www.nobility.by/forum/index.php?topic=3293.o.).

${ }^{29}$ Запись была недавно обнаружена белорусским историком Дмитрием Юркевичем. См. Собрание белорусской шляхты, дата обращения, Ноября 23, 2021, http://www.nobility.by/forum/index.php?topic=2116.o. (Sobranie belorusskoi shliakhty, data obrashcheniia, Noiabria 23, 2021, http://www.nobility.by/forum/index.php?topic=2116.0.). Елена Жидович упоминается также в справочнике: S. Konarski, Szlachta kalwińska w Polsce (Warszawa: [s.n.], 1936), 356.

${ }^{30}$ См. напр.: Бегунов, “Копиевский (Копиевич)," 122. (Begunov, “Kopievskii (Kopievich)," 122); В. И. Протасевич, “Илья Копиевич (Просветитель петровской эпохи)," в Из истории философской и общественно-политической мысли Белоруссии (Минск, 1962), 321. (V. I. Protasevich, "Il'ia Kopievich (Prosvetitel' petrovskoi epokhi)," in Iz istorii filosofskoŭ i obshchestvenno-politicheskoŭ mysli Belorussii
} 
Все они, однако, единодушны в том, что с детства Илья ходил в одну из кальвинистских школ. В Великом княжестве Литовском в этих школах обучали тогда чтению и письму на польском, литовском и русском языках (в белорусских землях), а также основам латыни, счету, катехизису и закону Божьему. ${ }^{31}$

О своей непростой судьбе в детские и юношеские годы Копиевский позднее рассказал сам в предисловии к переводу “Краткого собрания Льва Миротворца,” не вошедшем в печатное издание..$^{32}$ Из этого рассказа следует, что во время Русско-польской войны 1654 - 1667 гг. его отец пользовался покровительством русского царя, взявшего под защиту его имение (“а отцу моему пощадил великий государь, повелевши совсем дом его сохранити, придавши караул из двух трубачей, иже оглашаша, дабы никто не посмел во двор заехати, не токмо запаляти.") Однако во время похода на Ляховичи князя Хованского, поместье Копиевских все же было захвачено одним из русских воевод, который - очевидно, в расчете получить выкуп за его освобождение - увез Илью в новгородские земли. Случилось это когда тому было восемь или девять лет (“в девятом году”). ${ }^{33}$

Из плена, в который, как настаивает Копиевский, он попал вопреки царской воле (“полонения, противного наказу великаго государя”), ему удалось бежать, вероятно, в Москву, где он жил до своего освобождения в 1666 г. (“был под великим государем шесть лет.”) Свободу же он получил после визита в столицу уполномоченного Великого княжества Литовского Николая Цехановецкого. С ним Илья и вернулся на родину ("По шести же летех умилосердился великий государь и повелел меня пустити в свою землю с Цехановецким, воеводою мстиславским.") Его радость от освобождения из плена, однако, была омрачена новой бедой. Копиевский пишет, что по возвращению в родные края, “иезуиты, попы Римския веры” обвинили его в измене (“сказоваша, что я еретик изменник передался великому государю”) и убедили короля Казимира отобрать его имение. ${ }^{34}$

(Minsk, 1962), 321); “Капіевіч Ілья Федаравіч" в Беларускае замежжка (Мінск: Беларуская Энцыклапедыя імя Петруся Броўкі, 2010), 40. (“Kapijevič Ilija Fiedaravič," in Bielaruskaje zamiežža (Minsk: Bielaruskaja Encyklapiedyja imia Pietrusia Broŭki, 2010), 40).

${ }^{31}$ Nowak, "Eliasz Kopijewicz," 47.

${ }^{32}$ См. фрагмент этого предисловия: П. М. Строев, “Библиологический словарь и черновые к нему материалы," Сборник отделения русского языка и словесности Императорской академии наук, т. 29 (Санкт-Петербург: [б. и.], 1882), 179-18o. (Р. М. Stroev, "Bibliologicheskii slovar' i chernovye k nemu materialy," Sbornik otdeleniia russkogo iazyka i slovesnosti Imperatorskoi akademii nauk, t. 29 (St. Petersburg: [n.p.], 1882), 179-18o.). Дальше цитаты даются по этой публикации. Печатное издание перевода Копиевского: Лев VI Мудрый, Краткое собрание показующее дел воинских обучение (Амстердам: Тип. Ивана Андреева Тессинга, 1 января 1700). (Lev VI Mudryi, Kratkoe sobranie pokazuiushchee del voinskikh obuchenie (Amsterdam: Tip. Ivana Andreeva Tessinga, 1 ianvaria 170o)). Здесь и далее в статье библиографическое описания русских старопечатных книг составлены на основе стандарта РГБ. Вследствие запутанной и часто ошибочной пагинации изданий Копиевского цитаты из них во всех случаях приводятся без указания страниц.

${ }^{33}$ Копиевский благоразумно не называет имени своего обидчика - у него он просто “боярской сын с Бежецкия пятины." См.: Строев, “Библиологический словарь," 180. (Stroev, "Bibliologicheskii slovar'," 180).

${ }^{34}$ Король Казимир - Ян II Казимир Ваза, король Речи Посполитой. По-видимому, в данном случае было применено т.н. "арианское установление" (rejestr ariánski), часто использовавшееся иезуитами против кальвинистов-антитринитариев, которых a priori считали изменниками. В соответствии с ним разоблаченный изменник подлежал изгнанию, а доносчик получал в награду половину его имущества. Как считает Збигнев Новак, обвинение против Копиевского могло быть 
Сообщения историков о следующем повороте в его биографии снова расходятся. Одни считают, что, оставшись без средств к существованию, Илья почти сразу по возвращении из России отправился в Голландию. ${ }^{35}$ Другие - что это случилось позднее, после того как он успел поучиться в Слуцкой протестантской гимназии и поработать в ней лектором (преподавателем) младших классов. ${ }^{36}$ Упоминавшаяся выше метрическая запись кайдановской кальвинистской церкви о его вступлении в брак, свидетельствует о том, что это было именно так: после возвращения из России и до отъезда в Голландию Копиевский прожил в родных краях по меньшей мере 10 лет. ${ }^{37}$

Для него, кальвиниста, родившегося в полиэтничном, полилингвальном и поликонфессиональном Великом княжестве Литовском (по определению Вяч. Вс. Иванова “странном веротерпимом союзе разных религий и языков") выбор Голландии своим новым отечеством выглядит вполне естественным. ${ }^{38} \mathrm{~K}$ тому же в Республике Соединенных провинций, особенно в Амстердаме, тогда проживало немало его польских единоверцев, на помощь которых он мог рассчитывать. ${ }^{39}$

О первых годах жизни Копиевского в эмиграции историкам ничего не известно - эта страница его биографии еще ждет исследователей. Они лишь высказывают предположение, что в Голландии он получил какое-то дополнительное образование, необходимое для принятия сана священника реформатской церкви.

Самые ранние известия о его жизни в эмиграции относятся ко второй половине 169o-х гг. Они указывают на то, что какие-то деловые отношения с российскими властями у него были еще по меньшей мере за несколько месяцев до августа 1697 года, когда в Голландию прибыл Петр со своей свитой. Установлению этих отношений могли способствовать самые разные обстоятельства: годы, проведенные Копиевским в России в детстве, его беглый русский (“московский”) язык и, конечно, его образованность (помимо общих и специальных знаний, необходимых пастору, он свободно владел польским, голландским и латинским языками, а также в какой-то степени еще немецким и греческим). Вероятно, не последнюю роль в налаживании сотрудничества Копиевского с российскими властями играло и его затруднительное материальное положение.

подкреплено принесением им в 1659 г. присяги на верность русскому царю и годами пребывания в России. См.: Nowak, "Eliasz Kopijewicz," 49-50. Польский историк поясняет, что в то время присяга российскому государю не была чем-то исключительным. Ему присягала не только иноверческая, но и католическая шляхта, однако карательные меры по “арианскому установлению” применялись только к иноверцам.

${ }^{35}$ Nowak, "Eliasz Kopijewicz,” 50.

${ }^{6}$ Это мнение имеет документальное подтверждение: в списке преподавателей Слуцкой гимназии за 1674 г. значится “Илья Копиевич лектор.” См.: Глебов, Историческая записка о Слуцкой гимназии, 183. (Glebov, Istoricheskaia zapiska o Slutskol gimnazii, 183).

37 Збигнев Новак ошибочно считает, что Копиевский вступил в брак уже в Амстердаме. См.: Nowak, “Eliasz Kopijewicz," 51.

$3^{8}$ О языковой и культурной ситуации в Великом княжестве Литовском см.: Вяч. Вс. Иванов, “Языки, языковые семьи и языковые союзы внутри Великого княжества Литовского,” в Speculum Slaviae Orientalis: Muscovy, Ruthenia and Lithuania in the Late Middle Ages, под ред. В. В. Иванова, Ю. Верхоланцевой (Москва: Новое изд-во, 2005), 95. (Viach. Vs. Ivanov, “Iazyki, iazykovye sem'i i iazykovye soiuzy vnutri Velikogo kniazhestva Litovskogo," v Speculum Slaviae Orientalis: Muscovy, Ruthenia and Lithuania in the Late Middle Ages, pod red. V. V. Ivanova, Iu. Verkholantsevor̆ (Moscow: Novoe izd-vo, 2005), 95).

${ }^{39}$ Nowak, "Eliasz Kopijewicz," 50. 
Одним из свидетельств этого сотрудничества является уже упоминавшееся предисловие к Краткому собранию Льва Миротворца, датированное 15 июля 1696 г. Во включенном в него посвящении Петру он велеречиво утверждает, что перевод книги был осуществлен им в Амстердаме по воле русского царя: “великия же славы ради великого государя нашего, нашего царя государя и великого князя... по языку словенску от латинска честно переведена есть и достоверне в славном граде Амстеродаме, уничиженным рабом Илиею Копиевским." ${ }^{\circ}$ То есть получается, что Петр поручил ему эту работу по меньшей мере за год до своего прибытия в Голландию. ${ }^{41}$

Из этого же предисловия можно также заключить, что в середине 1696 г. Копиевскому были уже известны какие-то издательские планы Петра, и что он уже приступил к работе над их осуществлением. ${ }^{42}$ Не исключено, впрочем, что сотрудничество Копиевского с русскими в это время не ограничивалось переводами. Мы знаем, что 22 ноября 1696 г. по петровскому указу государевым стольникам было велено отправиться “в разные государства учиться всяким наукам,” и что 22 из них отбыли “для научения морского дела” в Голландию и Англию. ${ }^{43}$ Не стали ли они его первыми учениками?

\section{II. Во время Великого посольства}

\section{Преподаватель, переводчик, составитель учебных книг}

Встреча в Амстердаме с Петром и его окружением круто изменила жизнь Копиевского. В конце 1697 года он принимает решение отказаться от карьеры священника и посвящает себя исполнению петровского замысла по просвещению “славянороссийского народа”: преподаванию, переводам и составлению учебных книг. ${ }^{44}$

Прибывших в составе Великого посольства дворян и “волонтеров" он учил иностранным языкам, морскому делу, астрономии, и другим “наукам и искусствам.” По его словам, учеников у него было много и занимался он с ними интенсивно, причем не один месяц. Об этом он свидетельствовал в челобитной Петру 18 декабря 1699 года: "Известно есть твоему пресветлейшему величеству, колико я князей и дворян твоего пресветлейшаго царскаго величества учил более

\footnotetext{
${ }^{40}$ Строев, “Библиологический словарь,” 179. (Stroev, “Bibliologicheskii slovar',” 179).

$4^{11}$ У Збигнева Новака не вызывает сомнений, что это было именно так. См.: Nowak, "Eliasz Kopijewicz," 51.

${ }^{42}$ См.: М. А. Бобрик, “Материалы к биографии Ильи Федоровича Копиевского,” Известия АН СССР. Серия литературы и языка, 1 (1991), 78. (М. A. Bobrik, "Materialy k biografii Il'i Fedorovicha Kopievskogo,” Izvestiia AN SSSR. Seriia literatury i iazyka, 1 (1991), 78).

${ }^{43}$ М. М. Богословский, Петр I. Материалы для биографии, т. 1. (Москва: Соцэкгиз, 1940), 366. (М. M. Bogoslovskii, Petr I. Materialy dlia biografii, t. 1. (Moscow: Sotsėkgiz, 1940), 366).

44 “Славянороссийским народом” Копиевский обычно называет подданных Петра в предисловиях к своим книгам. Это название, восходящее к “Киевскому синопсису,” было широко распространено в конце XVII - начале XVIII в.
} 
году, а за тое не желал от них денег, аще же трудился, их ради, днем и нощию." Он сообщает здесь и имена некоторых своих учеников: стольника Семена Андреевича Салтыкова, князя Осипа Ивановича Щербатова, а также некоего “татачюка" (скорее всего, также прибывшего в Голландию в составе Посольства грузинского царевича Александра Арчиловича Имеретинского из рода Багратионов). ${ }^{46}$ Среди его учеников был и Петр Ларионов, прибывший в Амстердам вместе со своим отцом, подьячим Михайлой Ларионовым. Решив за казенный счет дать сыну европейское образование, Михайло направил царю челобитную, и вскоре в расходной книге Посольства появилась запись: "реформатскому пастору Илье Федорову за учение подьячего Михайлова сына Ларионова Петра и на покупку ему латинских книг 15 золотых." 47

Параллельно с преподаванием Копиевский работал над переводами с латыни и составлением учебников. За несколько месяцев им были подготовлены краткие пособия по мореплаванию, астрономии, арифметике, латинскому языку, и грамматике. Некоторые из этих небольших по объему рукописей он использовал в процессе занятий с учениками. Очевидно, Копиевский очень рассчитывал, что Петр поручит стать их издателем именно ему.

\section{Труды и дни в челобитной Головину}

О некоторых обстоятельствах первых месяцев этой новой жизни Копиевского мы узнаем из его челобитной президенту Посольских дел Ф. А. Головину, поданной в декабре 1697 г. $^{48}$ Поводом для обращения к главе российского дипломатического ведомства стал визит к Копиевскому некоего человека за рукописью перевода учебника по мореплаванию (“шыперской книги”), который к тому времени уже был им закончен. ${ }^{49}$ Свой труд Копиевский ему не отдал и теперь просил Головина подтвердить, что человек был послан действительно от него:

\footnotetext{
${ }^{45}$ Пекарский, Наука и литература в России при Петре Великом, т. 1, 522. (Pekarskii, Nauka i literatura $v$ Rossii pri Petre Velikom, t. 1, 522).

${ }^{46}$ Пекарский, Наука и литература в России при Петре Великом, т. 1, 522, 527. (Pekarskii, Nauka i literatura v Rossii pri Petre Velikom, t. 1, 522, 527). Некоторые историки считают, что среди тех, кого он учил немецкому языку, мог быть и сам Петр. См.: Н. А. Бакланова, "Великое посольство за границей в 1697 - 1698 гг. (Его жизнь и быт по приходо-расходным книгам посольства),” в Петр Великий: сборник статей, ред. А. И. Андреев (Москва-Ленинград: Академия наук СССР, 1947), 56. (N. A. Baklanova, "Velikoe posol'stvo za granitsei v 1697 - 1698 gg. (Ego zhizn' i byt po prikhodoraskhodnym knigam posol'stva)," v Petr Velikii: sbornik statei, red. A. I. Andreev (Moscow-Leningrad: Akademiia nauk SSSR, 1947), 56); Бобрик, "Материалы к биографии Ильи Федоровича Копиевского," 77. (Bobrik, "Materialy k biografii Il'i Fedorovicha Kopievskogo," 77).

47 Цит. по: М. М. Богословский, Русское общество и наука при Петре Великом (Ленинград: Российская государственная Академическая типография, 1925), 20. (M. M. Bogoslovskii, Russkoe obshchestvo i nauka pri Petre Velikom (Leningrad: Rossiiskaia gosudarstvennaia Akademicheskaia tipografiia, 1925), 20).

${ }_{48}$ Российский государственный архив древних актов (РГАДА), ф. 32, оп. 1, д. 67, л. 1-2. (Rossiiskii gosudarstvennyi arkhiv drevnikh aktov (RGADA), f. 32, ор. 1, d. 67, 1. 1-2.). Моя искренняя признательность О. Е. Кошелевой за помощь в прочтении этого документа.

49 Этот перевод был издан позднее: Авраам Деграф, Книга учащая Морского Плавания (Амстердам: Печатал Авраам Бреман, 24 ноября 1701). (Avraam Degraf, Kniga uchashchaia Morskogo Plavaniia (Amsterdam: Pechatal Avraam Breman, 24 November 1701)).
} 
По указу Величества Вашей Велможности, Государя моего многомилостиваго, совершил я книгу морскаго плавания, но не посмел никому в руки дать без повеления Величества Вашей Велможности, Государя моего многомилостиваго..5

Свой отказ челобитчик объяснял опасением быть обманутым, поскольку работа над книгой стоила ему не только многих трудов, но и серьезных финансовых затрат. О последних Копиевский сообщает особенно подробно. По его словам, отказавшись от пастырского служения, он лишился церковных доходов, в результате чего полгода жил за счет собственных сбережений, переехал в более скромное жилище и потратил тридцать рублей из собственных средств, включая расходы на нужды своих русских учеников:

...понеже, много трудился долгое время, покамест состроил сию книгу. Ея же ради во мнозе отщатился [=отщетился]. Болеи тритцати рублей денег своих потерал, дом свой покинувши иной нанял, дал десять рублей на желание дворян Великаго и Пресветлейшаго Государя, и все приходы церковные, от нашего собору амстеродаскаго мне даваные, всегда покинул, и тако с полгода сам харчуюся..$^{11}$

Эти подробности о понесенных им убытках Копиевский заключает подобострастным заверением о том, что совсем о них не жалеет, поскольку он понес эти жертвы во имя русского царя и российского государства:

И нескучно бы мне было, Пресветловелможный Государь, страдати славы ради Пресветлейшаго и Августейшаго Великаго Государя и ползы деля Преславнейшыя Речи посполитыя Славянороссийския, понеже сие есть намерение всех трудов моих в писании..$^{2}$

Однако все сказанное до этого момента является только прелюдией к главному содержанию челобитной - жалобе на учеников и нанесенный ими ущерб. Как выясняется дальше, они тайно переписали переведенную Копиевским “шыперскую книгу,” отдали ее другому наставнику (“мужику”) перешли к нему и стали насмехаться над своим прежним учителем:

Точию жалоба мне, Пресветло Велможный Государь, на тое, что дворяне Великаго и Пресветлейшаго Государя, переписавши Книгу мою туне, пошли с книгою к мужику простому, и ничево не умевшему кроме копаса, и то несовершенно. И негоде того, что там пошли

\footnotetext{
${ }_{50}^{5}$ РГАДА, ф. 32, оп. 1, д. 67, л. 1. (RGADA, f. 32, op. 1, d. 67, 1. 1).

${ }^{51}$ Ibid.

52 Ibid. Очевидно, "Речью посполитой Славянороссийской” Копиевский называет единение славянских народов под властью русского государя (польск. rzecz - “вещь, дело” и pospolita “общая”).
} 
учитися, сверх того поругаются мне и смеются с меня, взявши книгу безденежно. ${ }^{53}$

Разумеется, просить Головина о том, чтобы тот вернул обратно перебежчиков и вместе с ними потерянные доходы за их обучение, было бессмысленно. Однако Копиевский вполне мог надеяться на компенсацию за незаконное использование его перевода:

... и еще хотят и совершённую книгу взять без денег. Я на такое посрамление не дам книги, написал я [еe] толико Величеству Вашей Велможности Государю моему многомилостивому, и у подозия ног Величества Вашей Велможности [ее] покладаю, и низко бью челом. ${ }^{54}$

Никаких конкретных финансовых претензий он при этом не предъявляет, однако гордо провозглашает, что ценит свои труды высоко: “Никому же трудов моих не дам, потому что я безделицы никогда не пишу, и на всю вселенную не постыжуся вовеки, Божиею милостию, трудов моих." 55 Впрочем, дальше, как бы подсказывая Головину размер ожидаемой компенсации, Копиевский приводит пример составленной им латинско-русской грамматики, работа над которой потребовала от него гораздо меньше усилий. За эту грамматику, по его заверению, он получил 10 рублей - хотя мог продать ее и в полтора раза дороже:

Недавно написал я Грамматыку латинскую и рускую вкупе и продал за десять рублей, в чом на меня погневался един нарочитой челавек здешний - он хотел дать пятнадесять рублей и болеи за Грамматыку. О Морском же плаванию сотью более я трудившися, мог бы я на поругания дать им вторицею? ${ }^{56}$

Конкретное же предложение Копиевского состояло в том, чтобы Головин устроил публичное разбирательство этого случая. "Мужику" (теперь названному им “мастером") следовало приказать прийти с книгою, по которой тот учит перебежчиков, и, пригласив в качестве эксперта "наставника всех шыпров [=шкиперов] здешних,” в присутствии Копиевского рассудить, кто ее автор (“чия книга и наука будет”). ${ }^{57}$ Таким образом истина восторжествует, и “тот виноватый будет виноват пред Величеством Вашея Велможности Государем моим много милостивым. ${ }^{8} 8$ Копиевский явно рассчитывал, что после такого разбирательства ему хотя бы частично будут возмещены убытки, о которых он так подробно рассказал Головину. Впрочем, не исключено, что он надеялся на их компенсацию и без всякого разбирательства.

\footnotetext{
${ }^{53}$ РГАДА, ф. 32, оп. 1, д. 67, л. 1. . (RGADA, f. 32, op. 1, d. 67, 1. 1).

${ }^{54}$ Ibid., л. 1-1 об.

${ }^{55} \mathrm{Ibid}$., Л. 1 об.

${ }^{56} \mathrm{Ibid}$

${ }^{57} \mathrm{Ibid}$. , Л. 2.

${ }^{58}$ Ibid.
} 


\section{Труды и дни в челобитных Петру}

О всякого рода других невзгодах, постигших его в это время, Копиевский подробно рассказывает и в челобитных Петру. ${ }^{59}$ Он жалуется в них на кражу своего имущества учениками, обманы приказчиков, неуплату ему обещанных вознаграждений, несправедливые обиды.

С горечью сообщает Копиевский царю о краже двумя его учениками инвентаря: уехав из Амстердама, они не только не поблагодарили своего наставника за труды, но и прихватили с собой четыре дорогостоящих глобуса. К жалобе на них Копиевский не забывает добавить раболепную просьбу вернуть стоимость украденного (“глобусы мои поплатить”) и заверение, что этот бесчестный поступок подданных Петра не поколебал его рвения служить ему и дальше:

Вси же поехали и спасибо не сказавши за учение; но сопротивно мои же глобусы четыре, не заплативши, звезли: два - князь Осип Иванович Щербатов тые глобусы, которые были на индийском дворе. Два глобусы завезл Семен Андреевич Салтыков за тое, что я его долгое время учил и трудился его ради. Вся же сия претерпех великия ради славы твоего пресветлейшаго величества и не бысть ничто же мне препятием в трудах моих. ${ }^{60}$

Из жалоб Копиевского Петру мы также узнаем, что порядок и условия оплаты его трудов не были четко установлены. В одном месте он сообщает царю, что "со усердием труждается" в написании одной из книг, приводит в подтверждение этого ее план, однако затем просит сообщить, не изменилась ли государева воля: "На повторный указ твоего пресветлейшаго царскаго величества ждати готов, а без указу не смею, горести исполнен." ${ }_{11}$ И дальше снова повторяет просьбу сообщить, остается ли в силе государев приказ работать над этой книгой: “Пожалуй меня, холопа своего, повели, великий государь ... о написании книги меня увестить."

Помимо затруднительных организационных и материальных условий своей работы, Копиевский жалуется Петру также на несправедливые обиды, которые он претерпел от его подданных. Особенно подробно - на принесшее ему тяжкие моральные страдания унижение, которым был подвергнут подьячим Михайлой Ларионовым (тем самым, сын которого Петр учился у Копиевского). Возвращая от Федора Головина рукопись заказанного царем перевода Краткого собрания Льва Миротворца, Ларионов специально привел Копиевского “в поварню,” отчитал его там при всех присутствовавших и заявил: "У нас-де промышленных

\footnotetext{
59 Пекарский, Наука и литература в России при Петре Великом, т. 1, 521-527. (Pekarskii, Nauka i literatura v Rossii pri Petre Velikom, t. 1, 521-527).

${ }^{60}$ Ibid., 522.

${ }^{61}$ Речь идет о Книги политычной, которая, судя по всему, так и не была Копиевским закончена. Ibid., 522, 526.

${ }^{62}$ Ibid., 522.
} 
людей на Москве стегают!”63 Рассказав об этом Петру, Копиевский с нескрываемой обидой и горечью добавляет: "Мошно [от польск. moszna] дело, аще тех, котории хотят точно жалованье взять твоего пресветлейшаго царскаго величества денежное. Не таково было и есть мое намерение, а умножения и расширения ради великия славы твоего пресветлейшаго царскаго величества потрудился, и до ныне еще труждаюся. Не имел вины подьячий поругатися мне." ${ }^{4}$

\section{В типографии Тессинга}

Вопреки ожиданиям Копиевского привилегию на печатанье составленных и переведенных им книг Петр выдал не ему, а Яну Тессингу - амстердамскому купцу, не имевшему отношения ни к наукам, ни к книгоизданию. Почему Петр сделал такой выбор? Скорее всего, в первую очередь по экономическим соображениям: тратить государственные деньги на создание русской типографии за границей он не хотел, а у Тессинга, в отличие от неимущего Копиевского, денег для такого дела было предостаточно. О том же, что первоначально Петр намеревался предоставить право издания и продажи книг в России именно Копиевскому можно сделать вывод из челобитной Петру 4 августа 1700 г. Она была написана рукою Копиевского от имени амстердамского купца Яна де Ионга, с которым он в это время поддерживал деловые отношения (об этих отношениях будет сказано дальше). В этом документе совершенно недвусмысленно утверждается, что сначала Петр хотел поручить печатанье русских книг именно ему: "прежде Тесинга ему был дан указ твоего пресветлейшаго царскаго величества печатать книги, яко шыперскую книгу морского плавания на русском языке и прочия.” За этим утверждением, как будто в укор решению Петра, следует добавление: “И много книг он написал, точию не смеет печатать, зане Тессингу указаная ... дана грамота."65

После получения 17 мая 1698 г. Тессингом петровской привилегии, Копиевскому ничего не оставалось, как начать сотрудничество с купцом в качестве наемного работника. ${ }^{66}$ И хотя положение подчиненного в новом предприятии его явно не устраивало, он энергично взялся за дело. Именно им вероятно, единственным человеком в Амстердаме, способным разработать новый славянский шрифт - была проделана основная работа по созданию новой типографии.

\footnotetext{
${ }^{63}$ Пекарский, Наука и литература в России при Петре Великом, т. 1: 522. (Pekarskii, Nauka i literatura $v$ Rossii pri Petre Velikom, t. 1, 522).

${ }^{64} \mathrm{Ibid}$. Примечательно, что в дальнейшем Михайло проявлял трогательную заботу об обучении своего “Петрунюшки” за границей. См.: О. Е. Кошелева, Люди Санкт-Петербургского острова Петровского времени (Москва: О. Г. И., 2004), 282-283. (О. Е. Kosheleva, Liudi Sankt-Peterburgskogo ostrova Petrovskogo vremeni (Moscow: O. G. I., 2004), 282-283).

${ }^{65}$ Пекарский, Наука и литература в России при Петре Великом, т. 1, 528. (Pekarskii, Nauka i literatura $v$ Rossii pri Petre Velikom, t. 1, 528).

66 Об обстоятельствах выдачи привилегии Тессингу и ее содержании см.: Памятники дипломатических сношений древней России с державами иностранными, т. VIII (Санкт-Петербург: 2 Отделение собств. е.и.в. канцелярии, 1867), столбцы 1298-13о2. (Pamiatniki diplomaticheskikh snoshenii drevnei Rossii s derzhavami inostrannymi, t. VIII (St. Petersburg: 2 Otdelenie sobstv. e.i.v. kantseliârii, 1867), stolbtsy 1298-1302).
} 
Из-за того, что подчиненное положение в “друкарне,” созданной практически целиком его собственными усилиями, не давало покоя немалым амбициям Копиевского, его отношения с Тессингом с самого начала складывались непросто. Во всяком случае, все известные его высказывания о купце содержат те или иные упреки в его адрес. Так в челобитной Петру 18 декабря 1699 г. Копиевский жалуется, что плата, которую он получает за свои труды у Тессинга, несоразмерна его стараниям. Тем не менее, несмотря на эту несправедливость, он решил отказаться от поездки в Берлин к прусскому курфюрсту и остался в Амстердаме исключительно ради служения русскому государю: “не Тессинга ради - он не может мне заплатить противу великих трудов моих, в них же со усердием труждаюся." ${ }^{\prime 6}$

И позже при любой возможности Копиевский продолжает высказывать претензии к купцу в недооценке его роли в создании типографии, нерадении в исполнении петровского наказа по изданию русских книг и всякого рода интригах. В предисловии к вышедшей уже после разрыва их отношений Книге учащей морского плавания он заявляет, что опубликовать ее у Тессинга не смог изза его козней (не называя, правда, купца по имени): “К тому здешный житель Амстеродамский препятие великое соделал: и сам книг не печатал, и хотящым запрещал даже и сам издаше."68

\section{Издатель, автор, первопроходец}

Хотя большинство книг, изданных Копиевским в типографии Тессинга, содержало всего по нескольку десятков страниц, огромный объем проделанной им в это время работы не может не удивлять: за несколько месяцев им была подготовлена к печати и опубликована целая серия учебных книг: по истории, арифметике, астрономии, военному делу, два словаря и перевод басен Эзопа с параллельным латинским текстом. ${ }^{69}$ По его собственному свидетельству, эти

\footnotetext{
${ }^{67}$ Пекарский, Наука и литература в России при Петре Великом, т. 1, 522. (Pekarskii, Nauka i literatura $v$ Rossii pri Petre Velikom, t. 1, 522).

${ }^{68}$ Деграф, Книга учащая Морского Плавания. (Degraf, Kniga uchashchaia Morskogo Plavaniia).

${ }^{69}$ И. Ф. Копиевский, Введение краткое во всякую историю по чину историчному от создания мира ясно и совершенно списанное (Амстердам: Типография Ивана Андреева Тесинга, 10 апреля 1699). (I. F. Kopievskii, Vvedenie kratkoe vo vsiakuiu istoriiu po chinu istorichnomu ot sozdaniia mira iasno $i$ sovershenno spisannoe (Amsterdam: Tipografiiā Ivana Andreeva Tesinga, 10 aprelia 1699)); И. Ф. Копиевский, Краткое и полезное руковедение во аритметику (Амстердам: Типография Ивана Андреева Тессинга, 15 апреля 1699). (I. F. Kopievskii, Kratkoe i poleznoe rukovedenie vo aritmetiku (Amsterdam: Tipografiia Ivana Andreeva Tessinga, 15 aprelia 1699)); И. Ф. Копиевский, Уготование u толкование ясное и зело изрядное, краснообразнаго поверстания кругов небесных (Амстердам: Типография Ивана Андреева Тессинга, 1699). I. F. Kopievskii, Ugotovanie i tolkovanie iasnoe i zelo izriadnoe, krasnoobraznago poverstaniia krugov nebesnykh (Amsterdam: Tipografiiā Ivana Andreeva Tessinga, 1699)); Лев VI, Краткое собрание. (Lev VI, Kratkoe sobranie); Aesop, Притчи Эзоповы (Амстердам: Типография Ивана Андреева Тесинга, 170о). (Aesop, Pritchi Ėzopovy (Amsterdam: Tipografiia Ivana Andreeva Tesinga, 1700)); И. Ф. Копиевский, Номенклятор на латинском, русском и голландском языках (Амстердам: Печатал И. А. Тессинг, 17оo). (I. F. Kopievskii, Nomenkliator na latinskom, russkom i gollandskom iazykakh (Amsterdam: Pechatal I. А. Tessing, 1700)); И. Ф. Копиевский, Номенклятор на латинском, русском и немецком языках (Амстердам: Печатал И. А.
} 
труды были для него настолько изнурительны, что стоили ему душевного расстройства: “избыточных ради трудов преогорчих душу мою, сам един труждаяся и в строении книг, и в друкарне, обучая мастеров в сицевом деле.”о

Даже если посчитать, что патетика Копиевского в этом фрагменте избыточна, вряд ли стоит сомневаться, что издание книг в типографии Тессинга далось ему нелегко. И дело было не только в производственных трудностях, отсутствии квалифицированных помощников, недостатке у него образования или литературного таланта. Составляя и печатая свои учебники, Копиевский во многих случаях находился в положении первопроходца, вынужденного рассчитывать только на собственные силы. Не имея в Амстердаме возможности опереться на опыт кого-либо из русских печатников, ему пришлось создавать новую типографию фактически “с нуля." То же самое можно сказать и о составлении им русских учебников. Вряд ли в его распоряжении имелись славянские рукописные книги светского содержания - единственные источники для поиска аналогов европейской ученой терминологии в то время. Следовательно, Копиевскому приходилось самому эти русские аналоги конструировать (или даже выдумывать), то есть изобретать русский научный язык. $^{71}$

\section{Партнерство с де Ионгом}

Летом 1700 г. Копиевский разрывает отношения с Тессингом и создает новую типографию для продолжения издания книг, обещанных им Петру. ${ }^{72}$ Первой из этой типографии выходит двуязычная латинская грамматика, предназначавшаяся специально для русского читателя. В предисловии к ней он снова обращается к сюжету, который не раз излагал раньше в предисловиях к своим книгам и

Тессинг, 1700). (I. F. Kopievskii, Nomenkliator na latinskom, russkom i nemetskom iazykakh (Amsterdam: Pechatal I. A. Tessing, 1700)).

${ }^{70}$ Деграф, Книга учащая Морского Плавания. (Degraf, Kniga uchashchaia Morskogo Plavaniia).

${ }^{71}$ Nowak, "Eliasz Kopijewicz," 54. В этой связи следует заметить, что нередко высказывающиеся суждения относительно плохого знания Копиевским русского языка явно поверхностны. И составленные, и переведенные им книги, и его челобитные свидетельствуют как раз об обратном. Его “славянороссийский” язык действительно содержит немало украинизмов, полонизмов и галлицизмов, однако это было естественно для различных версий славянского языка, имевших тогда хождение в Московской Руси. Как замечает в этой связи Екатерина Крюк, “язык его произведений сочетает в себе черты русского и церковнославянского языка, а также у него встречаются украинизмы и полонизмы (что связано с влиянием “простой мовы” (или т.н. рутенского языка)).” См.: Е. К. Крюк, “Краткое и полезное руковедение во аритметыку' Ильи Копиевского: языковые и композиционные особенности." (Е. K. Kriuk, "Kratkoe i poleznoe rukovedenie vo aritmetyku' Il'i Kopievskogo: iazykovye i kompozitsionnye osobennosti), in Beiträge zum 18. Arbeitstreffen der Europäischen Slavistischen Linguistik (Polyslav): 3.-5. September 2014, Budapest (Wiesbaden: Harrassowitz Verlag, 2015), 120.

${ }^{72}$ Говоря о “типографии" Копиевского, нужно иметь в виду, что под этим словом в его время часто понимался набор шрифтов, набор пунсонов и матриц для их изготовления, или все это типографское оборудование вместе, за исключением стационарного печатного пресса. В списке обещанных Петру книг, отпечатанном Копиевским на отдельном листе в типографии Тессинга в декабре 1699 г., значилось 21 названия (4 книги изданных, 13 подготовленных к печати и 4 планирующихся к изданию). См.: Пекарский, Наука и литература в России при Петре Великом, т. 1, 523-526. (Pekarskii, Nauka i literatura v Rossii pri Petre Velikom, t. 1, 523-526). 
челобитных Петру. Он опять сетует здесь на затраченные им непомерные усилия на ее издание, на понесенные финансовые издержки и на отсутствие у него знающих славянский язык наборщиков. И к этому снова добавляет, что все эти усилия и трудности довели его до душевного расстройства. На русском (текст предисловия дается сначала на латыни) этот сюжет звучит особенно выразительно:

Геркулевым убо дерзновением восприях сие дело во имя Господне и запотихся [=вогнал себя в пот] воистинно не без тщеты иных дел совершения и имения моего. Своими денгами сооружих типографию на печатование сомою точию грамматыки и во едином месяцы избыточным тщанием, помощию же Божиею, сицевое дело, имуще последними караванами послати, соверших. И тако яве есть всем премудрым, всяк удобее узрит, колико аз понесл трудов в совершении сицева дела: не поразит мя жестоким каменем зависть. Умолчю же ныне о неразумивих типографах, которих учити нужда бысть мне самому, и их ради неумелости во мнозе прегорчих душу мою, и во мнозе оттщетихся [= понес урон]. Обаче же легко бысть, егда благо подвизается тягота. ${ }^{73}$

Привилегию на продажу Латинской грамматики в Голландии и Вестфалии Копиевский получил 17 сентября 1700 г. от правительства Республики Соединенных провинций. ${ }^{74}$ Однако совершенно очевидно, что он рассчитывал на продажу ее в России, чему препятствовала монополия на ввоз в страну книг славянской печати, выданная Тессингу. Чтобы ее обойти, Копиевский прибегает к помощи своего нового компаньона, которым теперь стал Ян де Ионг амстердамский купец, также как и Тессинг торговавший в России и также знакомый с Петром лично. ${ }^{75}$ Четвертого августа 1700 г. он составляет от имени Де Ионга уже упомянутую раньше челобитную Петру, с просьбой разрешить продажу

\footnotetext{
${ }^{73}$ Копиевский, Latina grammatica. (Kopievskii, Latina grammatica).

${ }^{74}$ Эта привилегия напечатана им в начале книги вместе с русским переводом.

75 De Jongh Woutters, Jan de Jong или Jean de Jonge. По-русски подписывался как "Ян де Юнг Эвоутсор” или как “Иван Иевлев Молодой.” Пекарский, Наука и литература в России при Петре Великом, т. 1, 16, 528. (Pekarskii, Nauka i literatura v Rossii pri Petre Velikom, t. 1, 16, 528). Вдова Копиевского называла его еще "Юнк Эвод." См.: И. Ф. Токмаков, “Дело о пожитках и книгах, оставшихся после умершаго переводчика Илии Копиевскаго (1715 г. 19 октября): Материалы для истории русской и иностранной библиографии в связи с книжной торговлей," Библиограф 4 (1885), 8o. (I. F. Tokmakov, "Delo o pozhitkakh i knigakh, ostavshikhsia posle umershago perevodchika Ilii Kopievskago (1715 g. 19 oktiabria): Materialy dlia istorii russkoi i inostrannoi bibliografii v sviazi s knizhnoi torgovlei," Bibliograf 4 (1885), 80). О сотрудничестве де Ионга и Копиевского см.: В. Raptschinsky, "Russische drukkerijen te Amsterdam, 2. Kopiewski," Maandblad Amstelodamum 3 (1935), 26-27. В рассказах о пребывании Петра в Голландии, собранных писателем и историком Яковом Шельтемой, говорится, что де Ионг был “известным негоциантом” (négociant distingué), и что в Саардаме он был представлен царю и имел с ним продолжительную беседу. См.: J. Scheltema, Anecdotes historiques sur Pierre-le-Grand et sur ses voyages en Hollande et à Zaandam dans les années 1697 et 1717 (Lausanne: Ducloux, 1842), 91. О голландских купцах Юнгах в России см.: Л. А. Тимошина, “Русский иноземец' XVII в. Владимир Иевлевич," Вестник "Альянс-Архео” 24 (2018): 57-115. (L. А. Timoshina, "Russkii inozemets' XVII v. Vladimir Ievlevich," Vestnik "Al'ians-Arkheo" 24 (2018): 57-115).
} 
в “великороссийском государстве” книги “латинския с русским толкованием."76 Судя по тому, что тираж книги вскоре попал в Россию, эта просьба де Ионга / Копиевского была удовлетворена. На это указывает также приведенная выше фраза Копиевского о том, что ему удалось организовать отправку книги в Россию “последними караванами” (очевидно, перед окончанием навигации).

Впрочем, к некоторым заявлениям Копиевского в этом предисловии (и, скорее всего, в других случаях) нужно относиться с осторожностью. В частности, слова о том, что он “своими денгами сооружих типографию” вряд ли стоит понимать так, что она была создана исключительно на его средства. Очевидно, что сразу после разрыва с Тессингом финансовую поддержку ему стал оказывать де Ионг. Такое заключение следует и из того, что челобитная о разрешении продажи Латинской грамматики была составлена от имени купца, а также из документов, свидетельствующих о развитии их дальнейших отношений. В частности, впоследствии де Ионг утверждал, что именно он оплатил следующее русское издание, вышедшее уже без указания названия типографии: “Gloria triumphorum \& trophaeorum / Слава торжеств и знамен побед” - панегирик на взятие Азова, написанный Копиевским "стихами поетыцкими."77

Эта книга также как и Латинской грамматика, была двуязычной: помимо русского она имела латинское название и содержала небольшой по объему латинский текст, т.е. формально относилась к категории книг “латинския с русским толкованием.” Здесь уместно добавить, что вряд ли компаньоны рассчитывали на коммерческий успех от ее продаж. Скорее, они преследовали иную цель: получить разрешение Петра на распространение их последующих изданий в России в обход привилегии Тессинга. И очень похоже, что вскоре они этого добились. Во всяком случае, в предисловии к Книге учащей морского плавания - третьей, изданной при участии де Ионга, Копиевский утверждает, что вышла она по распоряжению Петра: “дан мне был указ Великаго Государя на печатование сея книги."78

Сотрудничество Копиевского с де Ионгом на этом и закончилось. Вскоре после выхода Книги учащей морского плавания из печати между обоими возник спор, завершившийся в 1702 году судебным разбирательством, инициированным де Ионгом. Решение суда, по-видимому, было вынесено в целом в пользу истца - во всяком случае, “друкарню” Копиевский должен был у де Ионга выкупать, уплачивая ему ежегодно “по сороку по четыре рубли.” Правда, уже изданные в ней книги были признаны судом его собственностью. ${ }^{79}$

Суть претензий де Ионга к Копиевскому не вполне ясна. О них можно судить только по его невнятным обвинениям в челобитной Петру от июля 1703 г., где купец жалуется, что был “ограблен...обманщиком Ильей Копиевским.” Грабеж же, по его словам, заключался в том, что из изданной за его счет Книги учащей

\footnotetext{
${ }^{76}$ Пекарский, Наука и литература в России при Петре Великом, т. 1, 528. (Pekarskii, Nauka i literatura $v$ Rossii pri Petre Velikom, t. 1, 528).

77 И. Ф. Копиевский, Gloria triumphorum \& trophaeorum / Слава торжеств и знамен побед (Амстердам: Типография И. Ф. Копиевского, 12 октября 1700). (I. F. Kopievskii, Gloria triumphorum $\mathcal{E}$ trophaeorum / Slava torzhestv i znamen pobed (Amsterdam: Tipografiia I. F. Kopievskogo, 12 oktiabria 1700)).

${ }_{78}$ Деграф, Книга учащая Морского Плавания. (Degraf, Kniga uchashchaia Morskogo Plavaniia).

${ }^{79}$ См. об этом: Быкова, Описание изданий, напечатанных кириллицей, 327, 337. (Bykova, Opisanie izdanii, napechatannykh kirillitse
} 
морского плавания тот изъял “четыре листа или 32 страницы с фигурами” и скрылся с ними за границей (“держится ныне в Польше или в Пруссах”). ${ }^{80}$ Из этой челобитной можно также заключить, что сотрудничество де Ионга с Копиевским оказалось для купца убыточным. Он жалуется здесь Петру, что книги, в издание которых им были вложены собственные средства, продаются плохо: “Я печатанием книг и похвальных виршей к пользе вашего царскаго величества много убытку имею, понеже купцов и охотников в землях вашего царскаго величества зело мало."

\section{В поисках новых возможностей: Берлин}

Разрыв с де Ионгом, арест, наложенный судом на типографию, и отсутствие средств для ее выкупа вынуждают Копиевского покинуть Голландию. И поскольку его издательская деятельность к этому времени уже была известна за ее пределами, он решил попробовать продолжить ее в других европейских странах.

Первыми Копиевского-издателя приметили лютеранские пиетисты - еще по книгам, вышедшим в типографии Тессинга. Немцы рассчитывали с его помощью наладить печатанье переводной литературы религиозного содержания для распространения в России своей идеи надконфессиональной ecclesia universalis. ${ }^{82}$ Намек на этот их интерес мы видим в уже цитировавшейся челобитной Копиевского Петру от 18 декабря 1699 г., где он говорит о своем отказе ехать в Берлин к “курфирстовскому величеству." ${ }_{33}$ В дальнейшем интерес к славянскому “друку” Копиевского стало проявлять находившееся под сильным влиянием пиетистов Прусское научное общество, в 1701 году получившее статус королевского. На установление долговременного сотрудничества с Обществом и рассчитывал Копиевский, отправляясь в начале 1702 г. из Амстердама в Берлин вместе с рукописями своих сочинений и переводов.

Первоочередная цель его поездки заключалась в проведении переговоров с руководством Общества о создании при нем русской типографии. С немецкой стороны в обсуждении сотрудничества обеих сторон и подготовке текста договора принимал участие его президент Готфрид Вильгельм Лейбниц, в то время уже прославленный ученый, член Лондонского королевского общества и иностранный член Французской Академии наук. В документах имеются свидетельства того, что с трудами Копиевского он был знаком и раньше. В ноябре 1701 г. в адресованном королю Фридриху I проекте Propagatio fidei per scientias Лейбниц упоминал о намерениях вступить с Обществом в переговоры некоего проповедника, литовца реформатской веры, хорошо знающего славянский язык и

\footnotetext{
${ }^{80}$ Пекарский, Наука и литература в России при Петре Великом, т. 1, 17. (Pekarskii, Nauka i literatura $v$ Rossii pri Petre Velikom, t. 1, 17).

${ }^{81} \mathrm{Ibid}$.

${ }^{82}$ См.: E. Winter, Halle als Ausgangspunkt der deutschen Russlandskunde im 18. Jahrhundert (Berlin: Academie Verlag, 1953), 216, 217 et al.

${ }^{83}$ Пекарский, Наука и литература в России при Петре Великом, т. 1, 522. (Pekarskii, Nauka i literatura $v$ Rossii pri Petre Velikom, t. 1, 522).
} 
занимающегося составлением славянского словаря. ${ }^{84} \mathrm{~K}$ этим сведениям о “литовце” Лейбниц добавлял, что Петр выдал ему привилегию на печатание на славянском языке Библии и других религиозных книг, однако из-за интриг другого лица (также не названного по имени), их издание не началось. ${ }^{85}$ Потребность Общества в литературе на русском языке Лейбниц объяснял задачами миссионерской деятельности: путь протестантских проповедников в Китай шел через просторы России, где им также следовало щедро нести “слово Божье.” Для того же, чтоб их там гостеприимно принимали, разъяснял он, эти проповедники должны быть людьми образованными и полезными в практических делах: в геодезических измерениях, навигации, определении сторон света с помощью компаса и т.д. ${ }^{86}$

23 мая 1702 г. о намерении руководства Общества приступить к переговорам с Копиевским было объявлено в издававшихся в Гамбурге "Исторических записках.” Объявление это не было подписано, однако его содержание свидетельствует, что составлено оно либо со слов Копиевского, либо им самим. В нем, в частности, сообщалось, что по привилегии царя Московии в 1698 году Элиасом Копиевичем в Амстердаме была создана славянская типография. После этого в заметке приводился подробный список латинских названий его книг, как и во всех других списках Копиевского в трех частях: напечатанные, подготовленные к печати и запланированные. По содержанию этот список был лишь слегка обновлен по сравнению с напечатанным им в 1700 г. в Латинской грамматике. ${ }^{87}$

Переговоры вскоре начались, однако они были осложнены тем, что для ввоза книг в Россию в обход привилегии, полученной Тессингом (а не Копиевским, как считал Лейбниц), требовалось разрешение Петра. Чтобы преодолеть это препятствие в июне 1702 г. Общество направило запрос (“мемориал”) на получение такого разрешения русскому послу в Гааге Андрею Артамоновичу Матвееву. Черновик его, включающий мало кому известные подробности деятельности Копиевского, был явно составлен не без участия его самого. ${ }^{88} \mathrm{~B}$ "мемориале," в частности, сообщалось, что сначала Копиевский работал вместе с амстердамским купцом, получившим привилегию на печатанье "научных и

\footnotetext{
${ }^{84}$ A. Harnack, Geschichte der Königlich Preussischen Akademie der Wissenschaften zu Berlin. 2. Bd. (Berlin: Reichsdruckerei. 1900), 141-145; Быкова, Описание изданий, напечатанных кириллицей, 328. (Bykova, Opisanie izdanii, napechatannykh kirillitsel, 328).

${ }^{85}$ Второе неназванное Лейбницем лицо - это, скорее всего, Ян Тессинг. Т. А. Быкова считает, что это де Ионг, однако ко времени составления Лейбницем Propagatio fidei per scientias в ноябре 1701 г. оба еще были компаньонами (Книга учащая морского плавания вышла 24 ноября 1701 г.). Не совсем понятно, откуда Лейбниц взял сведения о том, что Петр дал этому “литовцу реформатской веры” привилегию на печатание “славянской Библии и других книг.” Возможно, он был знаком с первым печатным списком трудов Копиевского 1699 г., который к готовящимся к печати относил: “17) Biblia s. caepta sunt latine, russice, polonice, 21) Concordantiae bibliorum russice.” Заглавие списка свидетельствовало о том, что печататься эти книги будут в соответствии с привилегией Петра: "cum gratia et privilegio serenissimae Careae Majestatis, Amstelodami scripsit, ibidemque loci et typis mandavit.” Цит. по: Пекарский, Наука и литература в России при Петре Великом, т. 1, 523. (Pekarskii, Nauka i literatura $v$ Rossii pri Petre Velikom, t. 1, 523).

${ }^{86}$ См. подробнее: Harnack, Geschichte der Königlich Preussischen Akademie 2, 143-144.

${ }^{87}$ Historische Remarques, 167-168.

88 Дальше содержание передается по: Быкова, Описание изданий, напечатанных кириллицей, 329. (Bykova, Opisanie izdanii, napechatannykh kirillitsel̆, 329).
} 
душеполезных книг," а после его смерти, хотя многие искали сотрудничества с ним, опасаясь обмана, решил уехать из Голландии. Свои же услуги Обществу, как было сказано дальше, он предложил потому, что разделяет его цель "распространить свет знаний возможно шире у тех берегов и народов, которые меньше всего просвещены.” После этой декларации следовало заявление о намерении Общества организовать с помощью Копиевского типографию для печатания русских книг - на выбор царя или кого-то из его доверенных лиц. Документ предполагал также и возможный порядок их распространения: изданные книги “Копиевский будет доставлять в Гамбург или Архангельск для продажи специальным уполномоченным."

На переговорах, затянувшихся не на один месяц, шло обсуждение конкретных условий контракта, составленных на основе предложений “мемориала." Черновик проекта контракта, включавший финансовые условия работы типографии, был составлен лично Лейбницем, окончательная же его редакция была вынесена для обсуждения на пленарных заседаниях Общества 18 и 24 августа в присутствии Копиевского. После этих обсуждений переговоры еще некоторое время продолжались заочно, однако в ноябре были прерваны. ${ }^{90}$ Все известное об этих переговорах историкам говорит о том, что они шли трудно - то ли из-за неуступчивости сторон, то ли из-за нежелания Петра предоставить Обществу право на распространение его печатной продукции в России.

Для Копиевского, очень рассчитывавшего на создание русской типографии в Берлине, их провал стал очередной серьезной неудачей: он лишился не только перспективы улучшить свое бедственное финансовое положение, но и возможности удовлетворить свои амбиции лучшего в Европе издателя славянских книг. Оставшись без каких-либо источников существования и обремененный платежами по иску де Ионга, он стал искать любые возможности для возобновления своей издательской деятельности, ставшей главным делом его жизни. Для его продолжения ему теперь нужно было выкупить арестованную в Амстердаме “друкарню” и найти людей, заинтересованных в печатании славянских книг в Европе.

\section{В поисках новых возможностей: Копенгаген}

Не забывал Копиевский, конечно, и о своих прежних тесных связях с русским правительством и не терял надежду получить от него какую-то поддержку. В ноябре 1702 г. он переезжает из Берлина в Копенгаген по приглашению русского посла в Дании А. П. Измайлова, с которым летом встречался в Берлине. Однако этот переезд не оправдал его ожиданий: кроме переводов, платы за которые ему

\footnotetext{
${ }^{89}$ Ibid. Об отклике российского правительства на это послание Т. А. Быкова не сообщает. Ей известно лишь, что его должен был передать Матвееву русский посол в Дании Андрей Петрович Измайлов, находившийся в июне 1702 г. в Берлине.

90 О подробностях этих переговоров см.: Ibid., 329-332. Оставшийся нереализованным проект предполагал, что Копиевский возьмет на себя печать по заказу Академии не только русские, но и польские книги. См.: А. Harnack, Geschichte der Königlich Preussischen Akademie der Wissenschaften zu Berlin, bd. 1 (Berlin: Reichsdruckerei. 1900), 127.
} 
едва хватало на жизнь, никакой помощи от русской дипломатической миссии в Дании он не получил.

Между тем интерес к Копиевскому как издателю славянских книг не угас со стороны иностранных лингвистов и богословов евангельско-пиетистского направления. Одним из них был шведский ученый и дипломат Юхан Спарвенфельд, рассчитывавший с его помощью издать свой латинско-русский словарь, работе над которым он посвятил долгие годы и который считал главным трудом своей жизни. ${ }^{11}$ Другим известным ученым, заинтересованным в использовании русской типографии Копиевского, был автор вышедшей в 1696 г. в Оксфорде первой грамматики русского языка Генрих Лудоль $\phi .^{92}$ Последний был хорошо осведомлен не только о книгах Копиевского, но и о его переговорах со шведами об издании словаря Спарвенфельда. Об этих переговорах в 1703 г. он подробно сообщал в письме лектору “Конгрегации евангелизации народов" в Риме Ивану Пастричу (Ivan Paštrić, Iohannes Pastritius, Giovanni Pastrizio), допуская возможность переезда ученого “белоруса” в Швецию:

Славянский словарь Спарвенфельда не был напечатан в Амстердаме, как предполагалось: некий Илья Копиевич, белорус, напечатал в Амстердаме по царской привилегии различные русские книги и, между прочим, русско-латинскую грамматику, предназначенную для обучения латинскому языку русских. Доктор Бергиус, генеральный суперинтендант Ливонии в Риге, ведет переговоры с упомянутым Копиевичем о переезде его со своей типографией в Швецию для печатания словаря Спарвенфельда за счет короля. ${ }^{93}$

Внимание Лудольфа к Копиевскому было связано, однако, не со словарем Спарвенфельда, а с новой волной интереса немецких пиетистов к изданию религиозной литературы на русском языке. Этот интерес теперь инициировал их признанный глава - знаменитый богослов и педагог, профессор университета в Галле Август Франке. Имея обширные связи среди своих единомышленников, он вел переписку со многими из них в разных странах, включая Россию. В частности, среди его корреспондентов были пастор Глюк и его преемник Иоганн Паус, информировавшие его о происходившем в Москве. ${ }^{94}$

\footnotetext{
${ }^{91}$ О словаре Спарвенфельда и попытках его издания см.: U. Birgegård, Johan Gabriel Sparwenfeld and the Lexicon Slavonicum: His Contribution to 17th Century Slavonic Lexicography (Uppsala: Almqvist \& Wiksell, 1985).

${ }^{92}$ H. W. Ludolf, Grammatica russica ... Una cum brevi vocabulario rerum naturalium (Oxford: a Theatro Sheldoniano, 1696). См. о ней вступительную статью в книге: Русская грамматика Лудольфа: Оксфорд, 1696. Переиздание Б. А. Ларина (Ленинград: Ленинградский научно-исследовательский институт языкознания, 1937), 10-11. (Russkaia grammatika Ludol'fa: Oksford, 1696. Pereizdanie B. A. Larina (Leningrad: Leningradskii nauchno-issledovatel'skii institut iazykoznaniia, 1937), 10-11). См. новое переиздание в книге: Б. А. Ларин, Три иностранных источника по разговорной речи Московской Pуси XVI-XVII веков (Санкт-Петербург: Издательство Санкт-Петербургского Университета, 2002). (B. A. Larin, Tri inostrannykh istochnika po razgovornoi rechi Moskovskoi Rusi XVI-XVII vekov (St. Petersburg: Izdatel'stvo Sankt-Peterburgskogo Universiteta, 2002)).

${ }_{93}^{93}$ Цит. по: Ларин, Три иностранных источника, 516. (Larin, Tri inostrannykh istochnika, 516). О связях Копиевского с Лудольфом и Спарвенфельдом см. также: Birgegård, Johan Gabriel Sparwenfeld, 96-98. ${ }^{94}$ CM.: Winter, Halle als Ausgangspunkt der deutschen Russlandskunde, 218-219 et al.
} 
По свидетельству Копиевского, в 1702 г. Франке встречался с ним в Берлине для обсуждения возможностей их будущего сотрудничества. 95 Через полтора года их переговоры возобновились в Копенгагене при посредничестве находившегося там Лудольфа. 15 февраля 1704 г., явно с его подачи, Копиевский направляет Франке письмо с выражением готовности приступить к изданию русских книг в Галле. ${ }^{96}$ Из содержания этого письма следует, что к этому времени типография Копиевского уже находилась в Копенгагене, однако за нее ему еще оставалось выплатить значительную сумму - 100 империалов (100о рублей). Извещая Франке об этом обременении, Копиевский просил его “измыслить пути, способы и средства для высвобождения типографии.” Судя по сказанному дальше в письме, его финансовое положение в это время действительно было критическим. Он пишет, что готов отправиться в Галле, однако лишь при условии, что его снабдят “хоть какими-нибудь средствами на путешествие." И следом сетует на тягостные условия жизни в Копенгагене: "Что касается меня самого, то я сижу как в клетке, прельщенный господином московским послом многими посулами, однако начисто покинутый."97

Спустя четыре дня, 19 февраля, Лудольф информировал Франке о подробностях своих переговоров с Копиевским. Он подтверждал его намерение отправиться Галле и указывал сумму, которую Франке будет достаточно заплатить ему за славянские шрифты - 100 талеров. Из письма Лудольфа также следовало, что изза неуступчивости Копиевского его переговоры с ним проходили непросто.

До Галле Копиевский, видимо, так и не доехал, однако сделка с Франке все же была заключена: он, как и предлагал Лудольф, продал ему центнер своих шрифтов. ${ }^{98}$ Это, безусловно, существенно улучшило материальное положение Копиевского, однако не оправдало его ожиданий в целом: от сотрудничества с Франке он рассчитывал получить гораздо больше. В цитировавшемся выше письме от 15 февраля 1704 г. он предлагал ему не славянские шрифты, а свои услуги типографа и издателя собственных трудов:

Итак, - писал он, - если вам, почтеннейшему повелителю, будет благоугодно иметь в Галле московскую типографию заодно со мной и моими рукописями для продолжения сего великого дела, то я буду готов к вашим услугам. ${ }^{99}$

Очевидно, что проданные Франке шрифты составляли лишь часть типографии Копиевского. Остальную он по-прежнему надеялся использовать для печатанья

\footnotetext{
95 “В прошлом 1702 году в Берлине Достопочтимой Светлости Вашей я показал список моих трудов и упомянул о моей типографии." См.: Winter, Halle als Ausgangspunkt der deutschen Russlandskunde, 396.

${ }_{96}$ Письмо опубликовано полностью в: Winter, Halle als Ausgangspunkt der deutschen Russlandskunde, 396-397.

${ }_{97}$ Цит. по: Быкова, Описание изданий, напечатанных кириллицей, 332, 333. (Bykova, Opisanie izdanii, napechatannykh kirillitsel, 332, 333).

$98 \mathrm{Ibid}$. Этими шрифтами в Галле впоследствии было издано несколько книг. См.: T. Chelbaeva, "Русские книги из Галле в дискурсе формирования русского литературного языка нового типа." ("Russkie knigi iz Galle v diskurse formirovaniia russkogo literaturnogo iazyka novogo tipa"), $\mathrm{PhD}$ diss. (Martin-Luther-Universität Halle-Wittenberg, 2015). Nowak, "Eliasz Kopijewicz," 72. О русских изданиях в Галле в XVIII в. в целом: Winter, Halle als Ausgangspunkt der deutschen Russlandskunde.

99 Быкова, Описание изданий, напечатанных кириллицей, 333. (Bykova, Opisanie izdanii, napechatannykh kirillitsei, 333).
} 
русских книг, в частности, для издания латинско-русского словаря Спарвенфельда в Швеции. Как нам уже известно из письма Лудольфа Пастричу, посредником в переговорах об этом с Копиевским выступал магистр философии Николай Бергиус, автор вышедшего в Стокгольме в 1704 г. описания религии московитов и бывший лифляндский суперинтендант. ${ }^{100}$ Обсуждение условий соответствующего соглашения велись не один год и, к несчастью для Копиевского, снова находившегося в бедственном финансовом положении, окончились безрезультатно. Прерваны они были, по-видимому, не из-за его неуступчивости, а по каким-то политическим причинам, скорее всего, связанным с активизацией военных действий между Швецией и Россией. ${ }^{101}$

\section{В поисках новых возможностей: Гданьск}

Из Дании Копиевский перебрался на север Польши, в Гданьск. Почему именно туда? Очень похоже, что из-за неожиданного интереса, проявленного к изданию русских календарей профессором математики Торуньской гимназии Павлом Патером. ${ }^{102}$ Чтобы получить у короля Речи Посполитой Августа II необходимую для этого привилегию, он 23 января 1703 г. обратился с соответствующим запросом к бургомистру Торуни. В запросе помимо прочего говорилось, что единственная в Европе русская типография находится в Амстердаме, и что ее возглавляет Ян Копиевич (вместо Ильи Патер ошибочно назвал имя его племянника). О дальнейшей судьбе этого запроса ничего не известно, однако интерес к изданию русских книг в Польше до Копиевского каким-то образом дошел.

Еще одной причиной его переезда в Польшу могли быть надежды на возвращение родового имения Копиевских, некогда отобранного королем Казимиром. Такую возможность в то время открывало заключение союза Речи Посполитой с Россией в Северной войне. Что касается выбора Гданьска, то его можно объяснить амбициозными издательскими планами Копиевского, явно не собиравшегося ограничиваться печатаньем календарей. Для их реализации нужно было жить в большом городе с хорошими библиотеками и развитым книгопечатанием.

Прибыл Копиевский в Польшу, скорее всего, в середине 1705 г. По каким-то причинам издание русских календарей в Торуньской гимназии не состоялось, и он приступил к осуществлению своего нового проекта - составлению русской грамматики для иностранцев. Спустя несколько месяцев, в марте следующего 1706 года, работа над книгой была закончена, и она пошла в печать. Очень похоже, что сначала Копиевский рассчитывал издать ее в Гданьске, однако сделать это ему не

\footnotetext{
${ }^{100}$ N. Bergius, Exercitatio Historico-Theologica de statu ecclesiae et religionis Moscoviticae (Stockholm: O. Enaeus, 1704). О русских интересах Бергиуса-ученого см. в статье: П. Н. Берков, "Изучение русской литературы иностранцами в XVIII веке," Язык и литература 5 (1930): 87-136. (P. N. Berkov, "Izuchenie russkoi literatury inostrantsami v XVIII veke," Iazyk i literatura 5 (1930): 87-136).

101 Быкова, Описание изданий, напечатанных кириллицей, 328 (Bykova, Opisanie izdanii, napechatannykh kirillitsei, 328); Winter, Halle als Ausgangspunkt der deutschen Russlandskunde, 219.

${ }^{102}$ Nowak, "Eliasz Kopijewicz," 73-74.
} 
удалось. ${ }^{103}$ Поскольку шведские войска находились недалеко от города, гданьский магистрат запретил печатать в городских типографиях книгу, включавшую посвящение Петру. Издать же ее своим “друком” Копиевский не мог, поскольку для нее требовался латинский шрифт, которого у него не было. В итоге издателя удалось найти только в близлежащем Штольценберге, на который не распространялась юрисдикция городских властей. Там, в мало кому известной типографии Христиана Филиппа Гольтца, Руковедение в грамматыку и вышло. ${ }^{104}$ Поскольку основной текст книги был латинским, Копиевский рассчитывал, что разрешение на ее продажу в России им будет получено. ${ }^{105}$ Возможно даже, что он получил его от российских властей заранее, еще до того, как начал над ней работать.

\section{Переводчик Посольского приказа}

Между тем в марте следующего 1707 г. в Торуни расположилась штаб-квартира войск генерала Карла Рёнеке, и находившийся в двухстах километрах севернее Торуни Гданьск оказался под контролем русской военной администрации. ${ }^{106}$ Это обстоятельство способствовало новому сближению Копиевского с российскими властями. По всей видимости, в июле он отправляется из Гданьска в Варшаву, где в то время находился Петр, там пишет прошение о поступлении на государственную службу и после принятия присяги 30 августа зачисляется переводчиком в Посольский приказ. ${ }^{107}$

Поскольку текст этой присяги содержит важные подробности, связанные с его последующей судьбой, приведу его целиком:

Понеже Пресветлейший и Державнейший Великий Государь, Царь и Великий Князь Петр Алексеевич, самодержец Всероссийский и прочае и прочая изволил меня нижеподписанного принять в службу свою для книжних и иных переводов, которые трудами моими могут и печататися во всякой исправности, того ради обещаю и кленуся Богом, истиным Учителем, что его царскому величеству в пребывающее время той службы во всем верен и благонамерен буду без всякие хитрости, как подобает исправляти великому слуге пред Богом и человек. И о противных и непотребных Московскому Государству делех и ответях коресспонденцыи и книг не иметь, и ни которого зла или противности чинить не буду, но во всем должен ему, оному государству ползы имать. И по возвращении своему изо

\footnotetext{
${ }^{103}$ Nowak, "Eliasz Kopijewicz," 73-74.

${ }^{104}$ Копиевский, Руковедение в грамматыку. (Kopievskii, Rukovedenie v grammatyku). См.: Nowak, "Eliasz Kopijewicz," 75; P. Paluchowski, "Eliasz Kopijewicz i Christian Philipp Golz: chełmski epizod wydawniczy z przełomu XVII i XVIII wieku," in Historie gdańskich dzielnic Chetm (Gdańsk: Muzeum Gdańska, 2018), 1: 201-211.

${ }^{105}$ Как уже было сказано, Копиевскому и де Ионгу было разрешено продавать в России Латинскую грамматику, основное содержание которой также было изложено на латыни.

${ }^{106}$ Nowak, "Eliasz Kopijewicz," 79.

107 О приеме Копиевского на русскую службу см.: Быкова, Описание изданий, напечатанных кириллицей, 334. (Bykova, Opisanie izdanii, napechatannykh kirillitsei, 334).
} 


\begin{abstract}
Гданска как наискоряе по-прежнему быть мне к войскам его царского Величества где оные обретатися имеют, и явитца в Посолской походной канцелярии. Что учинено при написании руки моей свершав 1707 года месяца августа 30-го дни.
\end{abstract}

И в конце почерком Копиевского добавлено: “Илия Копиевский приписал рукою своею утвержая выше писаное."

Из содержания документа можно заключить, что составлен он был в Варшаве, где в то время находилась Походная канцелярия Посольского приказа, и что Копиевскому вскоре предстояла поездка в Гданьск. Одной из целей этой поездки, как сообщал Копиевский позднее в письме к Петру, было исполнение государева наказа о покупке иностранных книг по военному искусству, для чего из царской канцелярии ему было выдано 50 ефимок. В этом же письме он сообщал, что смог найти там только одну, “Браунову артиллерию,” которую и послал Петру. ${ }^{109}$ Однако в Гданьск он отправился не только и не столько с целью покупки книг, сколько для того, чтобы привезти остававшиеся там личные вещи и шрифты своей русской типографии.

\title{
Два ограбления
}

Поступление на государственную службу стало новым, последним крутым поворотом в биографии Копиевского. И, как и предыдущие, оно не принесло ему ни материального достатка, ни общественного признания, ни душевного покоя. К тому же его служба началась с новых несчастий: вскоре после вступления в должность, на пути из Гданьска в Варшаву, куда он направлялся со своими пожитками и “типографией,” Копиевский был ограблен, причем дважды.

Первый раз - шведами, отнявшими у него шрифты и некоторое время спустя начавшими печатать ими пропагандистские воззвания к населению областей, находившихся в зоне военные действий. Из-за возникших в этой связи опасений русского правительства произошедшее получило широкую огласку и имело большой политический резонанс.

Первое известное упоминание о нем содержится в письме Петра царевичу Алексею от 24 февраля 1708 г. ${ }^{10}$ На следующий день о случившемся и его опасных последствиях сообщалось в государевой грамоте, отправленной в Киев, Смоленск

\footnotetext{
${ }^{108}$ РГАДА, ф. 138, оп. 1, 1707, д. 47, л. 1-1 об. (RGADA, f. 138, op. 1, 1707, d. 47, 1. 1 - 1 ob.).

109 Пекарский, Наука и литература в России при Петре Великом, т. 1, 528. (Pekarskii, Nauka i literatura v Rossii pri Petre Velikom, t. 1, 528). См. об этом: Nowak, "Eliasz Kopijewicz," 79; Быкова, Описание изданий, напечатанных кириллицей, 335. (Bykova, Opisanie izdanii, napechatannykh kirillitsei, 335). Речь здесь идет о впервые изданном в 1682 году в Гданьске на немецком языке трактате Эрнста Брауна Novissimum Fundamentum \& Praxis Artilleriae Oder Nach itziger besten Manier Neuvermehrter und gantz Gründlicher Unterricht. Русский перевод его вскоре вышел в Москве: Э. Браун, Новейшее основание и практика артилерии (Москва: Московский Печатный двор, сентябрь 1709). (Ė. Braun, Noveishee osnovanie i praktika artilerii (Moscow: Moskovskii Pechatnyi dvor, sentiabr' 1709)).

1о Петр I, Письма и бумаги императора Петра Великаго, т. 7, вып. 1 (Петроград: Первая государственная типография, 1918), 77. (Petr I, Pis'ma i bumagi imperatora Petra Velikago, t. 7, vyp. 1 (Petrograd: Pervaiā gosudarstvennaia tipografiia, 1918), 77).
} 
и Псков. ${ }^{111}$ В ней, в частности, говорилось, что в русских городах появились “возмутителные письма," напечатанные шведами шрифтом Тессинга (на самом деле это был шрифт, изготовленный Копиевским позднее), и строго предписывалось всеми возможными средствами остановить их распространение. Более обстоятельно об этом случае рассказывалось в “Боярском приговоре” “Об открытии присылаемых от неприятеля из Данцига возмутительных писем и о задержании тех, кои с оными явятся." “Приговор” этот, составленный на основании императорского указа, зачитанного в Ближней канцелярии 1 марта 1708 г., разъяснял суть инцидента длинной цитатой из письма Петра царевичу. Приведу здесь начало этого разъяснения:

В письме Его Царскаго Величества из Чашникова 24 Февраля, которое получено в Москве того же месяца 29 числа, написано, что неприятель из Гданска целой друк слов Словенских, которыми печатал в Амстердаме Словенския книги Тессинг, и по смерти его, тот мастер, не имея чем кормиться, ехал к Нам и с оным друком, который ныне у него во Гданске, от неприятеля взят, теми словами множество всяких возмутительных писем напечатано во Гданске, которыя хочет через шпионов послать в Наши края. Чего для надлежит везде сие объявить всем и накрепко заказать, дабы сего зело смотрели везде, где такие письма явятся, чтобы приносили, а паче и тех ловили, которые оныя приносить будут. ${ }^{112}$

По-видимому, обеспокоенность русских властей захватом шведами шрифта Копиевского была нешуточной - как и реальная угроза, которую представляло распространение в российских владениях “переметных листов.” Во всяком случае, даже спустя несколько месяцев после произошедшего, 10 июля 1708 г., Петр повторно предупреждал об опасности шведских листовок Ивана Мазепу:

Господин гетман.

Понеже неприятель идет по Днепру вниз, и по тому и по протчим всем видам намерение ево на Украйну, того ради предлагаем вам сие: первое, чтоб вы по своей верности смотрели в Малоросийском крае какой подсылки от неприятеля, также переметных листов [для чего неприятель и друку во Гданске Словенскую взял] и всяко оные остерегали и пресекали и нам в том [ежели сами чего не можете одне учинить] совет и ведомость давали. ${ }^{13}$

Поскольку подробные обстоятельства этого ограбления историкам не известны, им остается лишь строить догадки о случившемся и даже сомневаться,

\footnotetext{
${ }^{111}$ Ibid., 414-415.

${ }^{112}$ Полное собрание законов Российской империи, т. 4: 1700-1712 (Санкт-Петербург: типография 2 Отделения Собственной е.и.в. канцелярии, 1830), 402. (Polnoe sobranie zakonov Rossiiskoi imperii, t. 4: 1700-1712 (St. Petersburg: tipografiia 2 Otdeleniia Sobstvennoi e.i.v. kantseliarii, 1830), 402).

${ }^{113}$ Петр I, Письма и бумаги, т. 8, вып. 1 (Москва-Ленинград: Издательство Академии наук СССР, 1948), 21. (Petr I, Pis'ma i bumagi, t. 8, vyp. 1 (Moscow-Leningrad: Izdatel'stvo Akademii nauk SSSR, 1948), 21).
} 
что Копиевский был ограблен. Неужели неприятель силой отобрал у него русский шрифт, заранее зная, каким образом его можно будет использовать в военных целях? Т. А. Быкова допускает, что на самом деле никакого ограбления не было, а Копиевский, доведенный до отчаяния своим бедственным материальным положением, просто решил продать шведам свой “друк." 114 Действительно, в челобитной Петру, отправленной в мае 1708 г. Копиевский не упоминает ни о каком ограблении шведами и сообщает лишь о втором ограблении, совершенном казаками: “И моих ради несчастков, в пути на меня напали казаки и тое румедишку [=пожитки] отнели и, сверх того, били меня довольно."15 На обоснованность предположения Т. А. Быковой могут косвенно указывать и формулировки письма Петра царевичу, повторенные затем в императорских грамотах. Ни в одном из этих документов не говорится, что “друк” был взят у Копиевского силой - он просто был у него “взят." Вероятно, Т. А. Быкова обратила внимание и на сообщение Петра о том, что “мастер” был беден (“не имея чем кормиться”). Для чего Петр сделал это добавление? Неужели в оправдание сделки Копиевского со шведами?

Второе ограбление Копиевского на пути из Гданьска в Варшаву, напротив, не имело широкого резонанса. Подробности о нем известны из его челобитной, поданной больше, чем через два года после случившегося, в феврале 1710 г. Теперь своими обидчиками он называет не шведов, а русских - казаков из полка Карла Рённеке. На реке Висла они, помимо его собственного имущества, отобрали две штуки швабского полотна на сумму тридцать ефимков, которые он вез в Варшаву по заказу графа Г. И. Головкина. Копиевский свидетельствует здесь, что полотно, купленное им за деньги графа, не было возвращено, и его стоимость не была компенсирована. Рассчитывая на то, что справедливость будет восстановлена, он указывает имя человека, которого надлежит привлечь к ответу: полковника Чамардина, “удержавшего” дорогостоящий заказ Головкина. ${ }^{116}$ Имела ли какие-то последствия эта челобитная, неизвестно.

\section{У Якова Брюса}

В первые месяцы службы в Посольской походной канцелярии Копиевский был прикомандирован к генерал-поручику артиллерии Якову Брюсу, редактировавшему тогда перевод той самой “Брауновой артиллерии,” которую он несколькими месяцами ранее купил в Гданьске и отправил Петру. ${ }^{117}$ Сначала он находился при Брюсе в Варшаве, а затем после нескольких переходов вместе с русским войском оказался в Смоленске. Совершенно очевидно, что это первое назначение не радовало ни самого Копиевского, ни его начальника.

\footnotetext{
${ }^{114}$ См.: Быкова, Описание изданий, напечатанных кириллицей, 334. (Bykova, Opisanie izdanii, napechatannykh kirillitsei, 334).

115 Пекарский, Наука и литература в России при Петре Великом, т. 1, 528. (Pekarskii, Nauka i literatura v Rossii pri Petre Velikom, t. 1, 528).

${ }^{116}$ РГАДА, ф. 138, оп. 1, 1710, д. 19, л. 1. (RGADA, f. 138, op. 1, 1710, d. 19, 1. 1).

${ }^{117}$ Петр I. Письма и бумаги, т. 7, вып. 2 (Москва-Ленинград: Издательство Академии наук СССР, 1946), 755-756. (Petr I. Pis'ma i bumagi, t. 7, vyp. 2 (Moscow-Leningrad: Izdatel'stvo Akademii nauk SSSR, 1946), 755-756).
} 
Об недовольстве новым подчиненным Брюса можно судить по его письму Петру, отправленному в конце мая 1708 г., где он просит перевести Копиевского в Посольский приказ в Москву под начало Гаврилы Головкина. Брюс объяснял свою просьбу тем, что в Москве от него будет больше пользы, и даже называл книги, переводами которых он мог бы там заняться:

Вашему величеству всеуниженно доношу, что уже тому с два месяца прошло, как явился у меня Копиевичь, который при мне живет без всякого дела, потому что мне в нем никакие помощи нет, для того что языку Немецкому неискусен; а зело б ему было кстати переводить книги Полские летописные, також и геометрическую, которыя по приказу вашего величества, я, купя, отдал, будучи в Варшаве, в Посолскую канцелярию; того ради не лутче-ли его отослать к Гавриле Ивановичю [Головкину], понеже мне ненадобен, о чем вашего величества повеления ожидати буду. ${ }^{118}$

Почти одновременно с Брюсом к Петру с похожей просьбой обратился Копиевский, ссылаясь на свою усталость от разъездов и желание регулярно получать содержание, соответствующее его должности:

И по сие число живу я без дела и где мне вашего величества годовое жалованье брать, того не определено. ... И быть мне в походе при старости не возможно ... Всемилостивый государь! Прошу вашего величества, да повелит державство ваше во определении дела моего быть за старостию в ином месте кроме здешняго походу, и чтоб вашею превысочайшею и щедролюбивою милостию в совершенство был делом и вашего величества жалованьем определен. ${ }^{119}$

Оба прошения были Петром удовлетворены, хотя и не сразу: Копиевский был отозван из Смоленска в Москву по распоряжению Головкина только четвертого сентября 1708 г. Ему был установлен ежегодный оклад и дано первое задание - во исполнение государевой воли перевести Введение в европейскую историю Самуэля Пуфендорфа:

Господин Копиевской,

По получению сего, изволь ехать из Смоленска с приложенным при сем письмом к Москве и явись в Посольском приказе дьяком и Секретарю, ибо определено тебе быть в том Посольском приказе для переводу книг, и давать жалованья по трактату (по 200 р. на год) ..., и приехав к Москве, сыщи Гисторию Буфендорфову Латинскую или

\footnotetext{
${ }^{118}$ Ibid., 756 .

119 Пекарский, Наука и литература в России при Петре Великом, т. 1, 528-529. (Pekarskii, Nauka i literatura v Rossii pri Petre Velikom, t. 1, 528-529).
} 
Немецкую и переводи оную на Русской язык (ибо Его Царское Величество оной изволит нужно требовать). ${ }^{120}$

В приложенном к этому распоряжению Головкина письме говорилось, что по прибытии Копиевского в Москву, секретарю и дьякам надлежит составить “указ Великого Государя, что ему быть в службе Его Ц. В. в Посольском приказе для переводу книг с иностранных языков (которых он умеет, а именно Латинскаго, Немецкаго и Голанскаго) на руской."121 Еще из одного документа Посольской канцелярии мы узнаем, что 27 сентября 1708 г. Копиевский с этим письмом явился в Приказ и уже на следующий день указ о его назначении был готов. ${ }^{122}$

\section{В Москве}

О жизни и работе Копиевского в Москве историкам известно очень немного. Он трудился над несколькими переводами, однако по каким-то причинам ни один из них не был опубликован. Рукопись Истории Пуфендорфа, над которой Копиевскому было велено работать при поступлении на службу, осталась неизданной в бумагах Посольского приказа. ${ }^{123}$ Помимо нее до нас дошла еще рукопись его перевода Истории Александра Македонского Квинта Курция Руфа. ${ }^{124}$ По сообщению вдовы Копиевского, среди завершенных им переводов были также три катехизиса. Вызванная 19 октября 1715 г. в Посольский приказ на допрос, она свидетельствовала, что это были “три книги катизмусы,” которые ее муж “сочинил и написал на словенском языке своею рукою ... о разных верах, выбирая из разных книг с латинского, 3 галанскаго, с полского языков." 25 Эти рукописи, по ее утверждению, были переданы П. П. Шафирову. Позднее она же принесла в Приказ еще черновики сделанных Копиевским переводов каких-то книг Ветхого и Нового Заветов и незаконченный латинско-польский лексикон. ${ }^{126}$

Известно еще, что помимо переводов Копиевский в 1710 г. принимал экзамен у Петра Ларионова - того самого, отец которого Михайло двенадцатью годами раньше подверг его публичному унижению и насмешкам, а теперь в качестве

\footnotetext{
${ }^{120}$ И. Ф. Токмаков, “Дело 1708 г. 4-19 сентября, о бытии в Посольском Приказе Илье Копиевскому при переводе Истории Пуффендорфовой и при прочих с Латинскаго, Немецкаго и Голландскаго языков переводах: Материалы для истории русской и иностранной библиографии в связи с книжной торговлей," Библиограф 5 (1886), 75. (I. F. Tokmakov, “Delo 1708 g. 4-19 sentiabria, o bytii v Posol'skom Prikaze Il'e Kopievskomu pri perevode Istorii Puffendorfovoi i pri prochikh s Latinskago, Nemetskago i Gollandskago iazykov perevodakh: Materialy dlia istorii russkoi i inostrannoi bibliografii v sviazi s knizhnoi torgovlei," Bibliograf 5 (1886), 75).

${ }^{121}$ Ibid.

${ }^{122}$ Ibid., 76 .

${ }^{123}$ Токмаков, “Дело о пожитках и книгах,” 81. (Tokmakov, “Delo o pozhitkakh i knigakh,” 81).

${ }^{124}$ Исторический очерк и обзор фондов Рукописного отдела Библиотеки Академии наук 1 (МоскваЛенинград: Издательство Академии наук СССР, 1956), 410. (Istoricheskii ocherk $i$ obzor fondov Rukopisnogo otdela Biblioteki Akademii nauk 1 (Moscow-Leningrad: Izdatel'stvo Akademii nauk SSSR, 1956), 410). См. также: Быкова, Описание изданий, напечатанных кириллицей, 339-340. (Bykova, Opisanie izdanii, napechatannykh kirillitsei, 339-340). Это сочинение Копиевский неоднократно указывал как книгу, подготовленную им к печати.

${ }^{125}$ Токмаков, “Дело о пожитках и книгах,” 8о. (Tokmakov, "Delo o pozhitkakh i knigakh,” 80).

${ }^{226}$ Токмаков, “Дело о пожитках и книгах,” 8о. (Tokmakov, "Delo o pozhitkakh i knigakh,” 8о).
} 
старшего подьячего ведал первым повытьем Посольского приказа. ${ }^{127}$ За прошедшие после учебы у Копиевского годы, Петр продолжил свое образование в Европе и успел поработать в российской дипломатической миссии во Франции. ${ }^{128}$ Теперь, по возвращении в Москву, он подал в Посольский приказ прошение о назначении на должность, соответствующую его знаниям и опыту (“чином и государевым жалованьем против наук моих и трудов”). На основании этого прошения 11 января 1710 г. в Приказе было решено “освидетельствовать его в науке иностранных языков.” Назначенная для этого экзаменационная комиссия состояла из трех переводчиков: Михаила Шафирова (младшего брата вицеканцлера барона П. П. Шафирова), Матвея Белецкого и Ильи Копиевского. Они проверили Петра на знания латинского, немецкого, французского и голландского языков и пришли к заключению, что он “в науках оных языков искусен и переводчиком тех языков может быть свободно.” 29

Больше никаких примечательных известий о московском периоде жизни Копиевского и его трудах в Посольском приказе не известно. Отсутствие заметных следов его деятельности в государственных документах и особенно тот факт, что за семь лет им не было опубликовано ни одной книги, дают историкам повод говорить о частичной утрате им работоспособности. ${ }^{130}$ Намеки на это, действительно, можно найти уже в документах о приеме Копиевского на службу. Так, в письме Головкина дьякам и секретарю Посольского приказа после подтверждения государева распоряжения о переводе Копиевским Истории Пуфендорфа дается наказ тщательно контролировать его работу: “и вы в том его понуждайте, чтоб с прилежанием оную переводил." ${ }^{\prime 11}$ А в петровском указе о принятии Копиевского в должность о том же самом говорится еще более определенно: “чтобы он, сыскав Гисторию Буфендорфову, с Латинского или Немецкого языка переводил на русское реченье с прилежанием, и в том его понуждать, дабы он в переводе оной книги продолжения не чинил."132

Правда, кое-что о жизни Копиевского в Москве можно узнать еще из трех документов, составленных после его смерти. Все они недвусмысленно говорят об одном: достатка в его московском доме не было и близко. Первые два - это

\footnotetext{
${ }^{127}$ Д. О. Серов, Администрация Петра I (Москва: О. Г. И, 2008), 53. (D. O. Serov, Administratsiia Petra I (Moscow: O. G. I, 2008), 53).

128 "В 205 г. [=1696] отпущен во Европские государства при великом посольстве для обучения цесарскаго [=немецкого] языка. И быв в тех государствах, приехал к Москве в 702 году и был на Москве год. В 703 г. отпущен паки в те же Европские государства для совершения в науках латинскаго и цесарскаго языков и для обучения французскаго языка. В 1705-1707 гг. был для его царскаго величества дел при после А.А. Матвееве у двора короля Французскаго и в Голландии за секретаря 2 года и в делах труды свои показал многие.” О немецких школах в Москве в первой четверти XVIII в. (1701-1715 г2.): Документы московских архивов, собранные С. А. Белокуровым и А. H. Зерцаловым (Москва: Общество истории и древностей российских при Московском университете, 1907), 243-244. (O nemetskikh shkolakh v Moskve v pervoi chetverti XVIII v. (1701-1715 gg.): Dokumenty moskovskikh arkhivov, sobrannye S. A. Belokurovym i A. N. Zertsalovym (Moscow: Obshchestvo istorii i drevnostei rossiiskikh pri Moskovskom universitete, 1907), 243-244). ${ }^{129}$ Ibid. 244.

130 Быкова, Описание изданий, напечатанных кириллицей, 340. (Bykova, Opisanie izdanii, napechatannykh kirillitsei, 340).

${ }^{131}$ Токмаков, “Дело 1708 г. 4-19 сентября," 75. (Tokmakov, “Delo 1708 g. 4-19 sentiabria,” 75.). Курсив мой - Ю.З.

${ }^{132}$ Токмаков, “Дело 1708 г. 4-19 сентября,” 76. (Tokmakov, “Delo 1708 g. 4-19 sentiabria,” 76). Курсив мой - Ю.3.
} 
прошения о материальной помощи его семье, лишившейся кормильца. 8 октября его вдова составила в Посольском приказе челобитную, в которой сокрушалась, что от мужа ей досталось немало долгов: “муж мой умре, а после ево остались долги многие, и мне рабе Вашей немочно тех долгов после ево оплатить.” И к этому прибавляла, что в доме даже нет денег, “чтоб его погребсти." 33 Об оставшихся после Копиевского долгах и бедственном положении осиротевшей семьи говорится и в поданном в январе 1715 года в Приказ прошении о выдаче вдове его годового жалованья. ${ }^{134}$ Последнее свидетельство бедности семьи Копиевских - это уже не раз цитировавшийся допрос в Посольском приказе, в ходе которого вдова покойного сообщила, что в счет долга в 8 рублей была вынуждена заложить "з десять" оставшихся после мужа латинских книг “жене Фонзалена" (возможно, имея в виду жену инженера-полковника, “немчина,” Вильяма фон Залена). ${ }^{135}$

\section{Persona}

\section{Человек с непростым характером}

Многое из известного нам о жизни Копиевского указывает на то, что это был человек с непростым характером. Об этом может свидетельствовать и его недолгое сотрудничество с Тессингом, сопровождавшееся постоянными конфликтами, и также кратковременное партнерство с де Ионгом, закончившееся судебным разбирательством, и его дальнейшие безуспешные поиски новых компаньонов. Однако еще больше оснований для такого предположения дают письменные свидетельства - как его самого, так и его современников.

Если не считать книг, то большинство дошедших до нас рукописей Копиевского - это его челобитные и письма, полные разного рода жалоб на своих многочисленных обидчиков. Вначале - на его учеников, подьячего Михайлу Ларионова, Тессинга, де Ионга, неумелых типографских работников, посольских приказчиков. Позднее, уже во время службы в Москве, к этому списку прибавляются новые. Сначала - на иноземца, золотых дел мастера Петра Вилнета, не вернувшего ему часть денег за взятые узду, хомут и сани. ${ }^{136}$ Затем на известного уже нам полковника Чамардина, присвоившего дорогостоящее полотно, купленное Копиевским по поручению графа Головкина. ${ }^{137}$ На продавцов изданных им книг, вводящих его в “обиду немалую и разорение.” ${ }^{8}$ Наконец, на шведа Яна Меера, избившего его человека и отнявшего у него лошадь с телегой. ${ }^{139}$

Помимо этого, в некоторыхписьмах Копиевского видны следы его амбициозного и эксцентричного характера. Лучшим примером здесь может быть то, которое он адресовал Королевскому Прусскому научному обществу во время

\footnotetext{
133 РГАДА, ф. 138, оп. 1, 1714, д. 29, л. 1 (RGADA, f. 138, op. 1, 1714, d. 29, 1. 1).

${ }^{134}$ РГАДА, ф. 138, оп. 1, 1715, д. 8, л. 1. (RGADA, f. 138, op. 1, 1715, d. 29, l. 1 ).

135 Токмаков, “Дело о пожитках и книгах,” 8o. (Tokmakov, “Delo o pozhitkakh i knigakh,” 8o).

${ }^{136}$ РГАДА, ф. 138, оп. 1, 1709, д. 130, л. 1 - 1 об. (RGADA, f. 138, op. 1, 1709, d. 130, 1. 1 - 1 ob.).

137 РГАДА. Ф. 138, оп. 1, 1710, д. 19, л. 1 - 1 об. (RGADA, f. 138, op. 1, 1710, d. 19, 1. 1 - 1 оb.).

${ }_{138}^{8}$ РГАДА. Ф. 138, оп. 1, 1710, д. 19, л. 1 - 1 об. (RGADA, f. 138, op. 1, 1710, d. 19, 1.1 - 1 оb.).

${ }^{139}$ РГАДА, ф. 138, оп. 1, 1710, д. 47, л. 1. (RGADA, f. 138, op. 1, 1710, d. 47, 1. 1).
} 
переговоров в Берлине. В самом начале этих переговоров одним из условий создания русской типографии Копиевский назвал включение себя в состав членов Общества. Когда же ему в этом было отказано, то в ответном письме он представил этот отказ как предложение сотрудничать с ним в качестве “поденного работника.” Следом заявил о своем желании прервать переговоры, однако сразу после этого высокомерно объявил, что, если Общество посчитает их прекращение невозможным, то он все же будет готов сотрудничать с ним, хотя не по доброй воле, а по принуждению. ${ }^{140}$

Странности поведения Копиевского отмечали и его современники. В частности, Лудольф, который, как уже было упомянуто, вел с ним в 1704 г. в Копенгагене переговоры о продаже славянских шрифтов. В письме к Франке он указывал на откровенно завышенные финансовые требования Копиевского ("Если бы бедняга был немного более уступчивым и не просил столько денег”) и добавлял, что бедственное положение ослабило его умственные способности (sein Elend den Kopf geschwächt). ${ }^{141}$ А спустя три года после этого о Копиевском как о “больном мастере" (kränklichen Meister) писал Александру Меншикову Генрих фон Гюйссен (правда, не указывая характер его болезни). ${ }^{142}$

Вполне можно допустить, что в последние годы жизни душевные расстройства Копиевского, о которых он сам упоминал раньше в связи с подготовкой к печати своих книг (“преогорчих мою душу”), усилились. Его нестабильное психическое состояние мог усугубить и личный кризис, вызванный невостребованностью в Москве его предыдущего опыта издателя русских книг. ${ }^{143}$ Но все это, конечно, догадки. Не вызывает сомнений лишь то, что со времени приезда в Россию и до конца своих дней он оставался малозаметным переводчиком Посольского приказа.

О семье Копиевского историкам известны лишь отрывочные сведения. Как уже говорилось, в 1676 г. он венчался с местной дворянкой Еленой Жидович в протестантской церкви Кайданова. От их брака у него родилась дочь Анна, которую в мае 1708 г. Копиевский упоминает в челобитной Петру, рассказывая о своих злоключениях на пути в Варшаву (“И изо Гданска взяв свою румедишку и дочь девицу, поехал к вашему царскому величеству”). ${ }^{144}$ Поскольку в не раз упоминавшемся письме Лудольфа к Франке 19 февраля 1704 г. сказано, что Копиевский собирался приехать в Галле с дочерью, то можно заключить, что к этому времени он уже был вдов.

В России он женился повторно, о чем свидетельствуют документы Посольского приказа. В частности, показания его вдовы Марьи и дочери от брака с Еленой Анны, к тому времени уже бывшей замужем за “иноземцем” портным Иваном Адиковым. ${ }^{145}$ По предположению Т. А. Быковой, в России у Копиевского родилось

\footnotetext{
${ }^{140}$ См.: Быкова, Описание изданий, напечатанных кириллицей, 33о. (Bykova, Opisanie izdanii, napechatannykh kirillitsei, 330).

${ }^{141}$ Winter, Halle als Ausgangspunkt der deutschen Russlandskunde, 217.

${ }^{142}$ Ibid., 221.

${ }^{143}$ Текст приведенной выше присяги недвусмысленно свидетельствует о том, что при поступлении на службу он рассчитывал на продолжение своей издательской деятельности в России (“переводов, которые трудами моими могут и печататися во всякой исправности”).

144 Пекарский, Наука и литература в России при Петре Великом т. 1, 528. (Pekarskii, Nauka i literatura $v$ Rossii pri Petre Velikom, t. 1, 528).

${ }^{145}$ Токмаков, “Дело о пожитках и книгах,” 8o. (Tokmakov, “Delo o pozhitkakh i knigakh,” 80).
} 
еще по крайней мере два ребенка. ${ }^{146}$ Такое заключение она делает на основании прошения от января 1715 г. его вдовы о выдаче ей причитающегося мужу жалованья за предыдущий год. В нем она просит “дать чем бог по сердцу положит в приказ, что б мне рабе вашей после мужа моего з детми своими сиротами во всеконечной скудости не быть и меж двор не скитатца." 147

Однако как звали русскую жену Копиевского, и идет ли речь в этих документах об одной женщине или двух - не ясно. В не раз упоминавшемся протоколе допроса в Посольском приказе от 19 октября 1715 г., изданном без указания источника, она названа Марьей Андреевной, а в двух прошениях о вспомоществовании, поданных в октябре 1714 г. и январе 1715 г. - один раз Катериной Андреевной, другой Марьей Андреевной. В первом случае - "Перевотчика Ильи Копиевского вдова Катерина Андреева дочь." ${ }^{48}$ Во втором - “перевотчика Ильинская жена Копиевского вдова Марья Андреева дочь." 149 Из этого вполне может следовать, что Копиевский был женат в России дважды. Хотя также не исключено, что в какой-то из этих документов просто вкралась ошибка писца.

\section{Исследования биографии Копиевского}

В историографии Копиевскому явно не повезло. О нем, правда, сказано немало в известном труде П. П. Пекарского, названного современником “библиотекой сведений о зачатках нашего умственного движения, возникшего из реформ Петра Великого."15о Однако эти материалы отрывочны и не создают целостного представления о его фигуре. Почти через сто лет после Пекарского к биографии Копиевского обратилась Т. А. Быкова, уделив особое внимание его книгоиздательской деятельности. Еще некоторое время спустя биографические сведения о нем обобщил и дополнил 3. Новак в статье, оставшейся почти незамеченной историками. Этими тремя работами список основных исследований биографии Копиевского и заканчивается. ${ }^{151}$

Как объяснить такое скромное внимание к составителю и издателю первых русских учебников? Ведь историками написаны десятки подробных биографий людей, оставивших гораздо менее заметный след в культурных преобразованиях петровского времени. Наверное, на это есть несколько причин, однако главной, скорее всего, является маргинальное положение его фигуры в общем контексте историографии российской истории.

\footnotetext{
146 Быкова, Описание изданий, напечатанных кириллицей, 338. (Bykova, Opisanie izdanii, napechatannykh kirillitsei, 338).

${ }^{147}$ РГАДА, Ф. 138, оп. 1, 1715, д. 8, л. 1. (RGADA, f. 138, op. 1, 1715, d. 29, 1. 1). Курсив мой - Ю.3.

${ }_{148}$ Катериной Андреевной она названа и в делопроизводстве по этому челобитью: РГАДА, $\phi .138$, оп. 1, 1714, д. 29, л. 1 об. (RGADA, f. 138, ор. 1, 1714, d. 29, 1. 1 оb.).

${ }^{149}$ РГАДА, ф. 138, оп. 1, 1715, д. 8, л. 1. (RGADA, f. 138, op. 1, 1715, d. 29, 1. 1).

${ }^{150}$ Цит. по: Е. Шмурло, “Пекарский Петр Петрович,” П. П. Пекарский, Путешествие академика Николая Иосифа Делиля в Березов в 1740 году (Санкт-Петербург: тип. Акад. наук, 1865), 82. (Е. Shmurlo, "Pekarskii Petr Petrovich," P. P. Pekarskii, Puteshestvie akademika Nikolaia Iosifa Delilia $v$ Berezovv 1740 godu (St. Petersburg: tip. Akad. nauk, 1865), 82).

${ }^{151}$ Пекарский, Наука и литература в России при Петре Великом, т. 1-2. (Pekarskii, Nauka i literatura $v$ Rossii pri Petre Velikom, t. 1-2); Быкова, Описание изданий, напечатанных кириллицей. (Bykova, Opisanie izdanii, napechatannykh kirillitsei); Nowak, "Eliasz Kopijewicz."
} 
Действительно, какое отношение к ней имеет уроженец Великого княжества Литовского, затем гражданин Республики Соединенных провинций и лишь в последние годы жизни - российский подданный. К тому же не православный, а кальвинист, по-видимому, остававшийся преданным своей вере до конца дней. Неясна и его этническая принадлежность: то ли белорус, то ли поляк, то ли литовец, то ли украинец, но явно, не “природный русский.” В общем, инородец и иноверец, каким-то чудом оказавшийся в роли просветителя православного “славянороссийского народа."

Что касается причин внимания к его фигуре трех названных выше авторов, то они вполне объяснимы, хотя и по-разному. В труде П. П. Пекарского, где Копиевский выступает одним из исполнителей воли Петра, присутствие подробных сведений о нем обусловлено историографической манерой автора, видевшего главной целью своих исследований строгое следование источникам. Не могла обойти вниманием его фигуру и Т. А. Быкова, автор образцового библиографического описания книг кириллической печати конца XVII - первой четверти XVIII в. Кем был человек, подготовивший и издавший за границей одиннадцать из описанных ею русских изданий? Отвечая на этот вопрос, на основе тщательного анализа разнообразных документальных материалов, ей удалось впервые воссоздать важнейшие эпизоды жизненного пути Копиевского. Обращение к его биографии 3. Новака, признавшего в нем поляка по происхождению, можно, по-видимому, объяснить его симпатией к соплеменнику. Опираясь на материалы Пекарского и Быковой и анализируя польские источники, он добавляет к истории жизни Копиевского новые штрихи, подчеркивая его значимый вклад в начало становления научного знания в России.

Если же говорить об историографии петровских реформ в области образования и культуры в целом, то второстепенное место, которое в ней отводится этому инородцу и иноверцу, не вызывает особого удивления. Хорошо известно, что большинство писателей, переводчиков и типографов в окружении Петра, особенно на начальном этапе его преобразований, составляли православные выходцы из Юго-Западной Руси, имевшие основательное богословское образование, а нередко и высокие церковные должности. Поскольку Копиевский в эту когорту никак не мог быть зачислен, он так и остался в историографии скромным “белорусским просветителем," вследствие места рождения гораздо больше известным и чтимым в Минске, чем в Москве.

Сказанное, конечно, вовсе не значит, что сегодня его имя и его труды забыты. Однако интерес к ним проявляют почти исключительно лингвисты, видя в Копиевском в первую очередь переводчика, автора грамматик (латинской и русской) и составителя двух трехъязычных словарей. ${ }^{152}$ Что касается других его

\footnotetext{
${ }^{152}$ См. некоторые недавние работы: М. К. Брагоне, “К истории русского Эзопа на рубеже XVII и XVIII веков," в Litterarum fructis: Сборник статей к бо-летию С. И. Николаева, ред. Н. Ю. Алексеева, Н. Д. Кочеткова (Санкт-Петербург: Альянс-Архео, 2012), 75-87. (М. К. Bragone, "K istorii russkogo Ezopa na rubezhe XVII i XVIII vekov," in Litterarum fructis: Sbornik statei k 6o-letiiu S. I. Nikolaeva, red. N. Iu. Alekseeva, N. D. Kochetkova (St. Petersburg: Al'ians-Arkheo, 2012), 75-87); L. Ronchi de Michelis, "Tra Amsterdam e Mosca: I. F. Kopievskij e una traduzione russa dei libri simbolici della chiesa riformata olandese" in I testi cristiani nella storia e nella cultura: prospettive di ricerca tra Russia e Italia, a cura di S. Boesch Gajano et al. (Rome: Pontifico Instituto Orientale, 2013), 251-264; И. Е. Кузнецова, "Отражение вариативности языковых единиц в “Номенклаторе’ И. Копиевского,” в Труды Института русского языка им. В. В. Виноградова. Вып. 2 (Москва: Институт русского языка им. В. В. Виноградова, 2014),
} 
учебных книг, то их содержание и их место в российском культурном ландшафте начала XVIII в., то эти темы стали привлекать внимание исследователей только недавно. Как и вопросы, связанные с распространением и популярностью его книг в России. ${ }^{153}$

Между тем, уже сегодня можно с уверенностью заключить, что издания Копиевского внесли заметный вклад в становление науки и образования в России начала XVIII в. Достаточно упомянуть, что благодаря им массовый русский читатель получил первый печатный учебник арифметики, первые руссколатинско-немецкий и русско-латинско-голландский словари, первые учебники латинской грамматики, всемирной истории, военного дела, астрономии, навигации. И кроме этого - первую русскую карту звездного неба и первый русский перевод античной классики (Эзопа). Как тут не захотеть узнать об их создателе как можно больше?

463-469. (I. E. Kuznetsova, “Otrazhenie variativnosti iazykovykh edinits v 'Nomenklatore' I. Kopievskogo," v Trudy Instituta russkogo iazyka im. V. V. Vinogradova. Vyp. 2 (Moscow: Institut russkogo iazyka im. V. V. Vinogradova, 2014), 463-469); Е. К. Крюк “Краткое и полезное руковедение во аритметыку' Ильи Копиевского.” (Е. К. Kriuk, “'Kratkoe i poleznoe rukovedenie vo aritmetyku' Il'i Kopievskogo").

153 См.: Ю. П. Зарецкий, "Всемирная история Ильи Копиевского (Перевод, истолкование, компиляция, адаптация, трансляция европейского исторического знания в Россию)," в История: переводить, понимать, оценивать (к юбилею М. А. Юсима), ред. П. Ю. Уваров (Москва: Институт всеобщей истории РАН, 2021), 447-467. (Iu. P. Zaretskiǔ, "Vsemirnaia istoriia Il'i Kopievskogo (Perevod, istolkovanie, kompiliatsiia, adaptatsiia, transliatsiia evropeiskogo istoricheskogo znaniia v Rossiiu)," v Istoriia: perevodit', ponimat', otsenivat' ( $k$ iubileiu M. A. Iusima), red. P. Iu. Uvarov (Moscow: Institut vseobshchei istorii RAN, 2021), 447-467); Ю. П. Зарецкий, "Проект Петра Первого по изданию светских учебников: осуществление замысла," Quaestio Rossica 4 (2021) (в печати). (Iu. P. Zaretskii, "Proekt Petra Pervogo po izdaniiu svetskikh uchebnikov: osushchestvlenie zamysla," v Quaestio Rossica 4 (2021) (in press). 